\title{
Winged bean (Psophocarpus tetragonolobus (L.) DC.) for food and nutritional security: synthesis of past research and future direction
}

\author{
Alberto Stefano Tanzi ${ }^{1,2}$ (D) Graham Ewen Eagleton ${ }^{3} \cdot$ Wai Kuan Ho ${ }^{1,2} \cdot$ Quin Nee Wong $^{1} \cdot$ Sean Mayes $^{2,4}$ (D) \\ Festo Massawe ${ }^{1,2}$ (iD
}

Received: 2 September 2018 / Accepted: 15 March 2019 / Published online: 25 March 2019

(c) The Author(s) 2019

\begin{abstract}
Main Conclusion Winged bean is popularly known as “One Species Supermarket” for its nutrient-dense green pods, immature seeds, tubers, leaves, and mature seeds. This underutilised crop has potential beneficial traits related to its biological nitrogen-fixation to support low-input farming. Drawing from past knowledge, and based on current technologies, we propose a roadmap for research and development of winged bean for sustainable food systems.
\end{abstract}

Reliance on a handful of "major" crops has led to decreased diversity in crop species, agricultural systems and human diets. To reverse this trend, we need to encourage the greater use of minor, "orphan", underutilised species. These could contribute to an increase in crop diversity within agricultural systems, to improve human diets, and to support more sustainable and resilient food production systems. Among these underutilised species, winged bean (Psophocarpus tetragonolobus) has long been proposed as a crop for expanded use particularly in the humid tropics. It is an herbaceous perennial legume of equatorial environments and has been identified as a rich source of protein, with most parts of the plant being edible when appropriately prepared. However, to date, limited progress in structured improvement programmes has restricted the expansion of winged bean beyond its traditional confines. In this paper, we discuss the reasons for this and recommend approaches for better use of its genetic resources and related Psophocarpus species in developing improved varieties. We review studies on the growth, phenology, nodulation and nitrogen-fixation activity, breeding programmes, and molecular analyses. We then discuss prospects for the crop based on the greater understanding that these studies have provided and considering modern plant-breeding technologies and approaches. We propose a more targeted and structured research approach to fulfil the potential of winged bean to contribute to food security.

Keywords Winged bean · Psophocarpus tetragonolobus $\cdot$ Underutilised legume $\cdot$ Crop improvement $\cdot$ Food security

\section{Introduction}

Electronic supplementary material The online version of this article (https://doi.org/10.1007/s00425-019-03141-2) contains supplementary material, which is available to authorized users.

Festo Massawe

festo.massawe@nottingham.edu.my

1 School of Biosciences, University of Nottingham Malaysia, Jalan Broga, 43500 Semenyih, Selangor Darul Ehsan, Malaysia

2 Crops for the Future, Jalan Broga, 43500 Semenyih, Selangor Darul Ehsan, Malaysia
Despite the rich variety of crops once cultivated around the world, since the beginning of the twentieth century there has been a consistent decline in the number of species included

3 Department of Planning, Ministry of Agriculture, Livestock and Irrigation, Nay Pyi Taw 15011, Myanmar

4 School of Biosciences, Faculty of Science, University of Nottingham Sutton Bonington Campus, Sutton Bonington, Leicestershire LE12 5RD, UK 
in our diets. Currently, more than half of our food comes from only three major cereal crops, cultivated at large scale in monocultures. This has resulted in a lack of sufficient agro-diversity (FAO 2010, 2015), making food production systems more vulnerable whenever more stressful conditions occur (e.g. drought, pests and diseases), such that monocropping systems could fail on a large scale, undermining production and availability of food (FAO 2010, 2011; Rattalino Edreira et al. 2011; Siebert et al. 2017; Zampieri et al. 2017). At the same time, lack of genetic diversity hampers the development of improved varieties of major crops, by reducing the availability of beneficial gene-combinations to incorporate into plant breeding programmes. There is now also a growing recognition of the value of the link between agrobiodiversity (defined as the number of different crop species in a system) and sustainability, socio-economic resilience and improved human health (Chappell and LaValle 2011; Pellegrini and Tasciotti 2014; Khoury et al. 2014; Adhikari et al. 2017; Dwivedi et al. 2017). For these reasons, neglected and underutilised crop species have received increased attention in recent years, thanks to their potential to preserve and increase agrobiodiversity, to improve nutrition, and to tolerate or resist abiotic and biotic stresses (FAO 2010, 2015; Mayes et al. 2012; Padulosi et al. 2013; Chivenge et al. 2015; Massawe et al. 2016; Adhikari et al. 2017; see also the African Orphan Crops Consortium initiative www.africanorphancrops.org). Not that this focus on forgotten crops for fresh purposes is a new phenomenon. In 1974, the US National Academy of Sciences (NAS) convened a select committee to carry out "an extensive survey of underexploited tropical plants" as possible crops for the future. Among 36 species they considered in detail (NAS 1975a), "the exceptional merits" of one particular plant, the winged bean (Psophocarpus tetragonolobus L. DC.), was singled out for special attention and for promotion to the agricultural research community (NAS 1975b). This is an underutilised leguminous species, cultivated mainly in hot and humid countries for its green pods, tuberous roots, mature seeds, and leaves. All these have been reported to be rich sources of protein, carbohydrate, vitamins, minerals and fibre (Gillespie and Blagrove 1978; Anonymous 1980; NAS 1981; Kortt 1983; Kadam et al. 1984; Henry et al. 1985; Kantha and Erdman 1986; Mnembuka and Eggum 1995). Winged bean's effective symbiotic associations with a broad spectrum of rhizobia strains make it a good nitrogen-fixer for low-input and self-resilient agricultural systems (Burkill 1906; Masefield 1961; Anonymous 1980; Ikram and Broughton 1980; Iruthayathas and Vlassak 1982; Klu and Kumaga 1999).

Despite the international attention dedicated to this crop during the 1970s and 1980s, research has been inconsistent ever since, and thus the crop remains cultivated mainly on a subsistence scale. While substantial information came from the initial efforts especially on plant development under different growing conditions and nutritional value, germplasm characterisation and trait dissection were difficult in the absence of molecular markers, at that point in time. Hence, a fresh approach could include phenotypic characterisation of broader germplasm, the implementation of new technologies for genetic diversity analysis and trait dissection (e.g. genotyping by sequencing, GBS), and the translation of knowledge from other crops. This would help to evaluate the variability within species at a genomic level, while developing our understanding of the crop's breeding system and of the inheritance of key agricultural traits. For some traits, these approaches could bring advantages where past efforts failed, for example, in altering plant growth habit/ architecture, in raising and stabilising yield of desired plant parts, and in guaranteeing the nutritional value and safety of end products. Revamped efforts have indeed started to take this path, with recent work on transcriptomic profiles and molecular marker development (Chapman 2015; Vatanparast et al. 2016; Singh et al. 2017; Wong et al. 2017).

The present review provides a detailed analysis of past research on the conditions that influence winged bean as a plant and as a crop. We provide a summary of experiments on the photothermal regulation of key developmental events, of its nodulation and nitrogen-fixation activity, of past breeding efforts, and of the key areas for future research. We also discuss the recent molecular approaches, especially those that have investigated genetic diversity and population structure. Drawing from past knowledge, and based on current technologies, we propose a roadmap for research and development of winged bean for future agricultural systems.

\section{Winged bean in brief}

Winged bean (Psophocarpus tetragonolobus (L.) DC.) is a dicotyledonous plant, taxonomically classified under the Fabaceae family, Papilionoideae subfamily (see supplementary materials for pictures of the plant, and its edible parts). It has a diploid genome $(2 n=2 x=18)$, consisting of a karyotype with three pairs of short and six pairs of long chromosomes (Harder 1992), recently determined at around $1.22 \mathrm{Gbp} / 1 \mathrm{C}$ in size (Vatanparast et al. 2016), while previous estimation by flow cytometry suggested a haploid genome size of $782 \mathrm{Mbp}$ (Bennett and Smith 1976). It is considered to have a cleistogamous floral system, which would usually imply autogamy, with self-pollination having been observed to take place before the large flowers open in the morning hours (Karikari 1972; Erskine and Bala 1976; Erskine 1980) (see supplementary material; figure F.1). Such observations have been supported by experiments with bagged flowers (Karikari 1972; Anonymous 1980), suggesting that insects are not required for pollination. Nonetheless, analysis of 
phenotypic markers (e.g. stem colour) have revealed a 7.6\% of out-crossing during the wet season in Papua New Guinea (PNG), facilitated by carpenter bees (Xylocopa aruana) (Erskine 1980). In support of this study, pollen obtained from fully opened flowers was found to be viable for approximately $24 \mathrm{~h}$ (Koshy et al. 2013a), while the stigma remained receptive for $33 \mathrm{~h}$ (Senayake and Sumanasinghe 1978), providing evidence for possible cross-pollination events.

Winged bean grows in hot, humid, equatorial countries of Southern Asia, Melanesia and the Pacific area (NAS 1975b; Khan 1982). It can be grown from sea level up to frost-free altitudes of about $2000 \mathrm{~m}$ above sea level, with its main presence found in India, Sri Lanka, Bangladesh, Myanmar, Thailand, Laos, Vietnam, Cambodia, Malaysia, Indonesia, Philippines and PNG (NAS 1975b; Khan 1976; Drinkall 1978; Eagleton 1999). Its centre of origin, though, is still a matter of dispute. Two contrasting hypotheses have been suggested. The first hypothesis suggests the origin of P. tetragonolobus to be the African continent, with either in situ domestication and migration (by human activity) of the domesticated species east, or trans-domestication of an African progenitor species from which winged bean has been derived later in the Indian Ocean rim of Asia. In support of an Africa-centric hypothesis, the chromosome number and karyotype pattern of winged bean are consistent with five Psophocarpus species from Africa (Khan 1976; Pickersgill 1980; Harder 1992): namely $P$. scandens, $P$. grandiflorus, $P$. palustris, $P$. lecomtei, and P. lancifolius (Harder and Smartt 1992). Attempts have been made to determine the possible wild African progenitor, identified as P. grandiflorus based on its morphological resemblance and shared susceptibility to the fungus Synchytrium psophocarpi (Smartt 1980; Harder and Smartt 1992), or as P. scandens, following the more recent phenetic (Maxted 1990) and cladistic (Fatihah et al. 2012) analyses. The second, alternative, hypothesis postulates that $P$. tetragonolobus is a species distinct from current African members of the genus (Verdcourt and Halliday 1978) and arose through a mechanism of allopatric speciation preceding any purposeful or unwitting processes of domestication. The main limitation of this hypothesis, which shifts the origin of winged bean towards the east, is the lack of wild forms of this species in Asia or Melanesia. Burkill (1906) believed that the linguistic and historical evidence pointed to the origins of winged bean on the western fringes of the Indian Ocean, while Vavilov (1951) placed it in his hypothesised Indian centre of crop domestication. Hymowitz and Boyd (1977), on the other hand, proposed a Melanesian centre of origin based on the discovery of a significant centre of genetic diversity for winged bean in the highlands of PNG. However, Khan (1976) who was the first to assess and report on this centre of diversity, suggested that the winged bean was in fact a relatively recent prehistoric introduction from the west into such area. Turning to modern molecular tools, Yang et al. (2018) carried out the first phylogenetic investigation through analysis of three regions in the chloroplast genome, and a nuclear internal transcribed spacer (ITS). The results showed that none of the four $P$. tetragonolobus accessions-originally from Nigeria, Liberia, and Malaysia-fell into any of the other three groups comprising of Psophocarpus genus members. The authors suggested the possibility that Verdcourt and Halliday were right in that winged bean could have a distinct history from the rest of the African species, and for which the progenitor has been lost or remains undiscovered. On the other hand, in contrast to attempts by earlier researchers, they reported success in hybridising winged bean with $P$. scandens, which could support this species as the closest relative after all, and whose progeny could form a bridge for future trait introgression from the African material.

Winged bean has a wide range of uses and most parts of the plant are consumed, depending on where the crop is cultivated. The young pods are a popular edible part across all cultivation areas, eaten raw or as a cooked vegetable (NAS 1975b; Sastrapradja and Aminah Lubis 1975), and in Indonesia mature seeds are roasted like peanut and boiled (NAS 1981). In PNG, immature seeds are consumed due to their pea-like taste (Claydon 1975; Okezie and Martin 1980). In Myanmar, Thailand, and PNG, boiled, steamed, baked, fried or roasted tubers are also consumed (NAS 1975b; Eagleton 1999) (see supplementary material; figures E.1 to E.5). Leaves and flowers are also consumed (NAS 1975b; Okezie and Martin 1980; Anonymous 1981), and younger parts are particularly appreciated when infected with the fungus $S$. psophocarpi in Java, Indonesia (Hymowitz and Boyd 1977). Green or purple young pods have been reported, with presence or absence of specks (Erskine and Khan 1977; NAS 1975b). The seed coat colour has been reported to range from cream (NAS 1975b; Anonymous 1982; Mohanty et al. 2013), black (Klu and Kumaga 1999), brown (NAS 1975b; Klu and Kumaga 1999; Mohanty et al. 2013), to purple and mottled colours (NAS 1975b).

Winged bean yield data are limited; however, reports have projected yields of up to $10 \mathrm{t} / \mathrm{ha}$ for green pods (Martin and Delpin 1978; Anonymous 1981; Erskine and Kesavan 1982), $2 \mathrm{t} /$ ha for mature seeds (Anonymous 1978; Khan and Erskine 1978; Nangju and Baudoin 1979; Thompson and Haryono 1980; Nakamura and Abe 1989), and 11 t/ha for tubers (Stephenson et al. 1979). Mature seeds production with support systems could also be increased by ratooning, in order to maximise cumulative yield from a single planting (Motior Rahman 1998). The data are mostly based on reports rather than peer reviewed literature. Future research should include more extensive and replicated studies, which include comparisons with other crops, to benchmark winged bean productivity with that of other leguminous crops. 


\section{Synthesis of past research}

Past efforts were, in part, directed by a dedicated research centre based in Sri Lanka, funded by the International Council for Development of Underutilized Plants, ICDUP (Anonymous 1980). Among research-led initiatives, an international trial was set up to evaluate a set of accessions from across different countries, not dissimilar from the recent worldwide evaluation of Quinoa (Chenopodium quinoa) (Bazile et al. 2016). Great emphasis was directed to five main areas:

1. growth and phenology assessment in different growing conditions (Herath and Ormrod 1979; Anonymous 1980, 1981, 1982; Rüegg 1981; Misra and Misra 1985; Okubo et al. 1992);

2. development of high seed-yielding varieties (Nangju and Baudoin 1979; Erskine 1981a; Arumugan and Perera 1989);

3. nutritional profiling of edible parts (Anonymous 1980; Kortt 1980; Gross 1983; Kadam et al. 1984; Prakash et al. 1987);

4. nodulation ability (Hildebrand et al. 1981c; Iruthayathas and Herath 1981; Iruthayathas and Vlassak 1982, 1987; Iruthayathas et al. 1985) and

5. biotic and abiotic-stress tolerance studies (Karikari 1978; Thompson and Haryono 1979; Rüegg 1981; Price et al. 1982; Weil and Khalil 1986; Prakash et al. 1987).

Following on from the initial concerted research effort, winged bean research activities have expanded to include further characterisation of anti-nutritional factors in mature seeds (Umemoto et al. 1992; Habu et al. 1992, 1997; Mukhopadhyay 2000) as well as factors affecting plant growth and development (Schiavinato and Válio 1996a, b). And more recently, development of genetic resources such as molecular markers for genetic diversity assessment (Mohanty et al. 2013; Chen et al. 2015; Wong et al. 2017; Yang et al. 2018) or clonal fidelity (Koshy et al. 2013b), and transcriptome studies (Chapman 2015; Vatanparast et al. 2016; Wong et al. 2017).

\section{Vegetative growth}

In winged bean, good vegetative growth of established seedlings requires warm, well-lit, humid conditions. Several studies have shown that a day temperature of around $27^{\circ} \mathrm{C}$ and a night temperature above $20^{\circ} \mathrm{C}$ is optimal (Wong and Schwabe 1979; Herath and Ormrod 1979; Anonymous 1980, 1981; Wong 1983; Schiavinato and Válio 1996a). Reduced plant survival rate and plant height was observed under high temperature of $36 / 31{ }^{\circ} \mathrm{C}$ as compared to $27 / 22{ }^{\circ} \mathrm{C}$, from the accessions collected from upland and lowland winged beans accessions. The growth suppression was found to continue even when the temperature was reduced to $33 / 28{ }^{\circ} \mathrm{C}$ (Anonymous 1980). Lenz and Broughton (1981), working with the PNG accession UPS99 demonstrated that soil temperature was more critical than temperature above ground. The authors suggested that the optimum soil temperature for both vegetative growth and root nodule development was around $25{ }^{\circ} \mathrm{C}$, whereas photosynthetic rates could be sustained at $35^{\circ} \mathrm{C}$, and $\mathrm{N}$-fixation (measured by acetylene reduction assay) in the nodules at $30^{\circ} \mathrm{C}$. There were, however, significant growth variations in response to different conditions. Herath and Ormrod (1979), working with a range of PNG and Sri Lankan accessions showed differences in leaf area, stomatal density, and total chlorophyll content among cultivars, and in response to temperature and daylength. The PNG accessions showed higher stomatal density than Sri Lankan accessions, while both groups showed higher values at a $25 / 20{ }^{\circ} \mathrm{C}$ temperature regime than at $30 / 25{ }^{\circ} \mathrm{C}$. Sri Lankan material was able to achieve greater shoot biomass accumulation than PNG individuals under any treatment combination, perhaps due to different photosynthetic rates, but, overall, the highest dry weights were achieved either at $25 / 20{ }^{\circ} \mathrm{C}$ with $14 \mathrm{~h}$ photoperiod, or at $30 / 15{ }^{\circ} \mathrm{C}$ with $11 \mathrm{~h}$ photoperiod.

In another experiment, a lowland Malaysian accession (M14/4) grown at $8 \mathrm{~h}$ daylength was found to achieve the highest total dry matter accumulation at a temperature of $26 / 26{ }^{\circ} \mathrm{C}$, with growth progressively decreasing at $32 / 18{ }^{\circ} \mathrm{C}$, $20 / 14{ }^{\circ} \mathrm{C}$, and $18 / 18{ }^{\circ} \mathrm{C}$. The day temperature of $18{ }^{\circ} \mathrm{C}$ was found to depress growth more than the night temperature of $14{ }^{\circ} \mathrm{C}$. When grown at an optimum temperature of $26 / 18^{\circ} \mathrm{C}$, the Malaysian accession M14/4 was reported to produce greater amount of dry matter per plant, higher relative growth rate and net assimilation rate, more leaves and main stem nodes at $16 \mathrm{~h}$ rather than $8 \mathrm{~h}$ daylength regime (Wong and Schwabe 1979; Wong 1983). This finding was generally supported by other studies (Sinnadurai and Nyalemegbe 1979; Schiavinato and Válio 1996a). However, at higher temperature regimes (e.g. $32 / 22{ }^{\circ} \mathrm{C}$ ) there was no significant increase in biomass accumulation under $16 \mathrm{~h}$, compared to $8 \mathrm{~h}$ daylength. This was, to an extent, in agreement with the previous findings from Herath and Ormrod (1979). However, at a constant $13 \mathrm{~h}$ photoperiod, a higher temperature regime of $30 / 25{ }^{\circ} \mathrm{C}$ led to higher dry mass accumulation and leaf area than under $25 / 20^{\circ} \mathrm{C}$, without significant differences between these two regimes with regard to plant height or number of leaves (Schiavinato and Válio 1996a). Taken together, these findings suggest that winged bean has an integrated response to temperature and daylength, with higher biomass accumulation under day temperature between 25 and $30{ }^{\circ} \mathrm{C}$ and short-day photoperiod. However, substantial variation was observed between different accessions, 
when more than one was analysed, for traits like stomatal density, which could lead to different responses under suboptimal growth conditions (e.g. longer daylength and higher temperature).

In the field, winged bean is less tolerant to soil moisture deficits than most tropical legumes. In assessing $36 \mathrm{com}-$ mon leguminous crop species found in the tropics, Rachie (1977) classified winged bean as one of six crops grown mainly in the humid zone requiring an annual rainfall of $1500 \mathrm{~mm}$ and above. It is also virtually the only one in the humid zone found growing at altitudes over $1000 \mathrm{~m}$ a.s.l. Nevertheless, in Ghana winged bean has been grown without irrigation, although the yield was reduced below its expected maximum when the annual rainfall dropped below $1120 \mathrm{~mm}$ (Anonymous 1978, 1980). Similarly, Nangju and Baudoin (1979) found that winged bean (TPt2) seed yield was almost double that of cowpea (Vigna unguiculata), but lower than elite cultivars of soybean (Glycine max), pigeon pea (Cajanus cajan), and jack bean (Canavalia ensiformis) when grown at Nigerian site (Ibadan $7^{\circ} \mathrm{N}$ ) with annual rainfall of $1200 \mathrm{~mm}$ on string vertical support. On the other hand, winged bean was the top performer in another site with a moist environment of $2400 \mathrm{~mm}$ annual rainfall (Onna $5^{\circ} \mathrm{N}$ ). This would suggest that winged bean has greater water requirement for optimal growth compared to other legumes. A further drought screening with a larger set of winged bean germplasm from different ecotypes could reveal variation in response to water deficit stress.

\section{Effects of daylength and temperature on reproductive development}

Winged bean is a short-day species, exhibiting photothermal sensitivity during developmental progression towards flowering, pod production, and initiation of tuberous roots. Flower bud development seems to be inhibited by long daylength (more than $13 \mathrm{~h}$ daylength), although this depends on day/night temperature as well as genotype (see also "Vegetative growth" section above). A study conducted in Ghana
(Accra, $5^{\circ} 30^{\prime} \mathrm{N}$ ) using the accession TPt 1 from IITA (International Institute of Tropical Agriculture) showed days to $50 \%$ flowering to vary from 40 to 130 days between December (daylength of $11 \mathrm{~h} 50 \mathrm{~min}$ ) and March (daylength $12 \mathrm{~h}$ 25 min) planting (Sinnadurai and Nyalemegbe 1979). The authors attributed this shift in flowering timing principally to the change in daily photoperiod. Further studies carried out by Eagleton (1983) included TPt 1 along with another 24 accessions from Malaysia, PNG, Sri Lanka, Thailand, and Indonesia. Trials were conducted with trellising/staking structures across a range of planting dates between October and December in Malaysia (Serdang $3^{\circ} 8^{\prime} \mathrm{N}$ ) and in two locations in Western Australia (between $31^{\circ}$ and $34^{\circ} \mathrm{S}$ ). Overall, accessions began to flower during March in the Australian environment, irrespective of planting date or temperature conditions during vegetative growth stage, and significantly later than in the Malaysian trial (57 days in average $v s$ a minimum of 116 days in Australia). TPt1, followed by UPS99 (PNG) were the least affected accessions by change of daylength between the two environments, while M13/1 (Malaysia) showed greater dry mass accumulation during the same period. Eagleton and colleagues concluded that for subtropical conditions it could be feasible to exploit the variation in accessions collected from different ecotypes. Seed yield in Australia could be improved by sowing in spring, and in combination with early flowering, early maturing genotypes. Nakamura and Abe further explored such variation to select for individuals less sensitive to long days, starting with 44 accessions retrieved from different countries and seed banks (including IITA) (Abe and Nakamura 1983). Through their selection under subtropical conditions in Japan (Okinawa, $24^{\circ} \mathrm{N}$ ), they found in particular that the cultivar named "Urizun", derived from the Malaysian M13-1, was the least affected by sowing date (tested for every 2 months, between January and September). Flowering began only 65 days after sowing in May (14 $\mathrm{h}$ photoperiod), half the time required by TPt2 and UPS31 (PNG), with authors reporting a projected yield of $2 \mathrm{t} / \mathrm{ha}$ in spite of a growing season shorter than 6 months (Abe et al. 1988; Nakamura and Abe 1989).

Table 1 Summary of accessions and treatment imposed in some of the main phenological studies in controlled conditions on flowering in winged bean

\begin{tabular}{|c|c|c|}
\hline References & Accession (origin) & Daylength and temperature (day/night) regimes \\
\hline Eagleton et al. (Anonymous 1980) & UPS32, UPS47, UPS121 (PNG) (Malaysia) M13/1 & $10-, 12-, 14-\mathrm{h} ; 26 / 16^{\circ} \mathrm{C}, 27 / 22^{\circ} \mathrm{C}, 33 / 28^{\circ} \mathrm{C}$ \\
\hline Herath and Ormrod (1979) & $\begin{array}{l}\text { SL3, SL7, SL8, SL11, SL17, SL18 (Sri Lanka) UPS31, } \\
\text { UPS45, UPS46, UPS59, UPS61, UPS66, UPS78, } \\
\text { UPS80, UPS102 (PNG) }\end{array}$ & $11-, 14-\mathrm{h} ; 25 / 20^{\circ} \mathrm{C}, 30 / 25^{\circ} \mathrm{C}$ \\
\hline Wong and Schwabe (1979) & M14/4 (Malaysia) & $8-, 16-\mathrm{h} 32 / 18^{\circ} \mathrm{C}, 26 / 26^{\circ} \mathrm{C}, 26 / 14^{\circ} \mathrm{C}$ \\
\hline Rüegg (1981) & $\begin{array}{l}\text { Kade1-26 UPS32, UPS122 (PNG) TPt8 (retrieved } \\
\text { from IITA) }\end{array}$ & $12-\mathrm{h} 22 / 18^{\circ} \mathrm{C}, 27 / 23^{\circ} \mathrm{C}$ \\
\hline Uemoto et al. (1982) & $\begin{array}{l}\text { nine, including UPS31, UPS62, UPS99 (PNG) } 1 \text { (Sri } \\
\text { Lanka); } 1 \text { (Thailand) }\end{array}$ & $\begin{array}{l}\text { 8-, } 11-, 13-\mathrm{h} ; 20{ }^{\circ} \mathrm{C}, 25^{\circ} \mathrm{C}, 30^{\circ} \mathrm{C} \text { (constant day } / \\
\text { night) }\end{array}$ \\
\hline
\end{tabular}


In addition to field studies, experiments conducted under controlled environments have provided more evidence on how temperature and daylength (alone or in combination) control the phenology of winged bean, and revealed the genotypic variation that exists among different winged bean accessions (see a summary of the experiments in Table 1). For example, Herath and Ormrod (1979) reported that none of the 6 Sri Lankan and 15 PNG accessions flowered under $30 / 25{ }^{\circ} \mathrm{C}$ temperature regime at either 11 - or 14 -h photoperiod. Flowering was observed only in the 11 -h photoperiod in a $25 / 20^{\circ} \mathrm{C}$ temperature, with PNG accessions producing significantly more racemes (14) and flowers (31) within the first 60 days of growth, compared to Sri Lankan material (average of 5 racemes and 15 flowers), where 3 accessions failed to flower completely. By contrast, Rüegg (1981) found that in short daylength $(12 \mathrm{~h})$ the actual time to flowering in accessions from PNG, Nigeria, Ghana, and Costa Rica was shortened by warmer temperatures $\left(27 / 23{ }^{\circ} \mathrm{C}\right)$ compared to cooler conditions $\left(22 / 18{ }^{\circ} \mathrm{C}\right)$, leading to the highest grain yield for all accessions in the experiment. The UPS99 accessions (PNG) was among the earliest to flower under the optimal experimental conditions, and the least affected under lower temperature compared to the other accessions. This overall trend reported by Rüegg, in disagreement with Herath and Ormrod's findings, was also reported by Eagleton et al. (1983) in a controlled environment experiment with another four winged bean accessions of Malaysian and mainly PNG origins.

Uemoto et al. (1982) investigated raceme budding in nine PNG and two Asian (from Sri Lanka and Thailand) accessions mainly under 8-, 11-, or 13-h daylength regimes, with temperatures of $20^{\circ}, 25^{\circ}$, or $30^{\circ} \mathrm{C}$. They concluded $12 \mathrm{~h}$ being the critical daylength threshold for most of the genotypes, although UPS99 was able to produce buds at up to $15 \mathrm{~h}$ of daylength when kept at $20^{\circ} \mathrm{C}$. Moreover, in a following experiment, when UPS99 seedlings were raised in inductive conditions of $20{ }^{\circ} \mathrm{C}$ mean temperature and 8 -h daylength until second trifoliate leaf stage, they continued to produce plentiful buds even when the daylength was subsequently extended to $16 \mathrm{~h}$ (8-h natural light and 8-h incandescent light). The relative stability of the phenology of UPS99 in response to photothermal variability (Rüegg 1981; Uemoto et al. 1982; Eagleton 1983), was also reported in the first international (12 tropical and subtropical locations ranging from $1^{\circ} \mathrm{N}$, Singapore to $27^{\circ} \mathrm{N}$, Nepal) replicated field trials in which UPS99 was the earliest to flower among ten PNG and three Asian accessions. Even so, the overall mean for the number of days to flower across all sites was as much as 62 days after sowing (DAS) for UPS99, 67 DAS for all PNG accessions taken as a group, and 87 DAS for the mean of the three Asian accessions (Anonymous 1981; Eagleton et al. 1985).

Wong and Schwabe (1979) and Wong (1983) inferred from the Malaysian accession (M14/4), under a thorough controlled environment examination, that the 'critical' daylength for flower induction was between $11 \mathrm{~h} 15 \mathrm{~min}$ and $12 \mathrm{~h} 15 \mathrm{~min}$. A reduction in light intensity, during part of the photoperiod, lowered this critical daylength. At short, potentially inductive daylengths, the optimal day temperature was found to be $26^{\circ} \mathrm{C}$, whereas $32{ }^{\circ} \mathrm{C}$ or $18{ }^{\circ} \mathrm{C}$ inhibited flowering, again in broad agreement with most of the other studies. In an apparent contrast to the study by Uemoto et al. (1982) with UPS99, Wong (Anonymous 1981) reported that further bud development through to anthesis in the Malaysian accession did not take place if plants were returned to long days without the sufficient number of short days.

Rüegg (reported in Anonymous 1980) identified a very useful variant of the IITA accession TPt8, during controlled environment studies. The author followed the development of four diverse accessions, TPt8 (IITA), Kade1-26, UPS32 and UPS121 (PNG), at two temperature regimes finely calibrated to simulate field conditions at upland and lowland sites in PNG; namely, Wau at $1200 \mathrm{~m}$ a.s.l. $\left(22 / 18^{\circ} \mathrm{C}\right)$ and Lae at sea level $\left(27 / 23^{\circ} \mathrm{C}\right)$. Plants flowered even at a daylength of $16 \mathrm{~h}$ at $22 / 18{ }^{\circ} \mathrm{C}$ but not at $27 / 23{ }^{\circ} \mathrm{C}$. In general agreement with the mentioned studies, Schiavinato and Válio (1996a), using an Indonesian accession, found that, at a daylength of $13 \mathrm{~h}$ a temperature regime of $25 / 20{ }^{\circ} \mathrm{C}$ was required for flower induction and that flowering was delayed in regimes of $20 / 15{ }^{\circ} \mathrm{C}$ or $30 / 25{ }^{\circ} \mathrm{C}$ (96 and 63 days after germination, respectively).

In several studies (see Table 2) individuals exhibiting beneficial reduced photothermal sensitivity have been found in some of the accessions. This demonstrates that

Table 2 Accessions and variants with particular phenological traits across studies

\begin{tabular}{|c|c|c|}
\hline References & Location & Description \\
\hline Kim (Anonymous 1981) & Seoul, South Korea $\left(37^{\circ} 34^{\prime} \mathrm{N}\right)$ & Variant of UPS63 (PNG) that flowered earlier than UPS99 \\
\hline Okubo et al. (1992), Endo et al. (1993) & $\begin{array}{l}\text { Kyushu University, Japan; } \\
\text { Iwate Prefecture, Japan } \\
\left(39^{\circ} 42^{\prime} \mathrm{N}\right)\end{array}$ & $\begin{array}{l}\text { Detection of several completely photo-insensitive varieties for summer } \\
\text { pod production; two of these, KUS8 and KUS12, planted in May } \\
\text { yielded } 19 \text { and } 16 \text { t/ha of pods, respectively }\end{array}$ \\
\hline $\begin{array}{l}\text { Rüegg (Anonymous 1980), Eagleton } \\
\text { and Sandover (1984) }\end{array}$ & $\begin{array}{l}\text { Controlled environment; } \\
\text { Kununurra, Australia } \\
\left(15^{\circ} 46^{\prime} \mathrm{S}\right)\end{array}$ & $\begin{array}{l}\text { Early flowering variant of TPt8 renamed TPt8-ETH1 was less photo- } \\
\text { thermal sensitive. Tested in Australia, it flowered } 64 \text { DAS }\end{array}$ \\
\hline
\end{tabular}


photothermal-insensitive genotypes could be selected from large screening of germplasm, potentially leading to identification of different individuals with different genetic base for this trait, as shown in crops like soybean (Watanabe et al. 2012; Xu et al. 2013a) and common bean (Phaseolus vulgaris) (Kwak et al. 2008).

\section{Photothermal regulation of tuberisation}

The TPt8-ETH1 variant identified by Rüegg (Anonymous 1981) was the first to flower at the peak of the annual daylength and temperature cycle in the field experiment in Australia (Eagleton and Sandover 1984) (see Table 2) and produced its first mature seed pods 132 days after planting. The TPt8-ETH1 variant also gave the highest yield of root tubers, $939 \mathrm{~g} / \mathrm{m}^{2}$ when all plots were harvested in mid-August, 8 months after planting. Rüegg (1981) demonstrated that Tpt8 and UPS122 produced higher tuber yield at $22 / 18^{\circ} \mathrm{C}$ than at $27 / 23^{\circ} \mathrm{C}$, the reverse of what was found for pod and seed yields. This concurred with the findings of extensive multisite field trials in PNG which showed that upland locations produced higher tuber yields on average than lowland sites; while, again, the reverse was the case for pod yields, as suggested by Kesavan, and Stephenson and colleagues (Anonymous 1981). These findings have also been supported by Schiavinato and Válio (1996a) who found that a temperature of $30 / 25^{\circ} \mathrm{C}$, individuals failed to initiate any tubers while at $25 / 20{ }^{\circ} \mathrm{C}$ they produced significantly more tubers with a higher overall root dry weight yield than a temperature of $20 / 15^{\circ} \mathrm{C}$. There is ample evidence to suggest that tuber development in winged bean requires short days (Okubo et al. 1992; Wong and Schwabe 1979; Wong 1983). For example, Wong and Schwabe (1979) reported that M14/4 plants grown under 16-h daylength produced no tubers. Wong (1983) also found that reducing the intensity of daylight below $1100 \mu \mathrm{mol} \mathrm{m} \mathrm{m}^{-2} \mathrm{~s}^{-1}$ inhibited tuberisation. As was the case for flowering, plants had to be at least 5 weeks old before tubers could be initiated by inductive daylengths (see also Okubo et al. 1992). However, unlike for flowering, tuber development proceeded even under non-inductive conditions. Okubo et al. (1992) reported that some winged bean accessions (see Table 2) that appeared to have reduced photoperiod sensitivity for flowering, were also relatively photoperiod insensitive for tuber initiation, a finding that echoes a report by Eagleton and Sandover (1984).

Overall, the findings have shown that both temperature and daylength control the onset of flowering and tuberisation in winged bean. The variation shown by accessions from different areas might be related to the ecotype and where such accessions have been cultivated and undergone the initial adaptation process. There is therefore the potential to find improved material that could lead to the development of early maturing and higher yielding varieties of winged bean, able to flower and produce tubers beyond the current geographical distribution.

\section{Nodulation and $\mathbf{N}_{\mathbf{2}}$-fixation activity}

Winged bean plant has great capacity to nodulate (see supplementary material; figure N.1), fix nitrogen and survive on a range of tropical soils: from poor acidic clay and loam soils in Puerto Rico (Anonymous 1980), to sandy, swamp peats and heavy clay soils in Myanmar and PNG (Burkill 1906; Khan et al. 1977). Across repeated experiments in different locations in Malaysia, Masefield (1957) reported fresh nodule yields of up to $21 \mathrm{~g}$ per plant, which exceeded cowpea, common bean, groundnut (A. hypogaea) and $G$. soya. In Puerto Rico, on an uninoculated oxisol with no history of prior legume cultivations, Harding et al. (1978) observed greater numbers and weight of nodules from eight winged bean accessions (from PNG and IITA collection) than from four other tropical legumes [soybean (G. $\max \mathrm{cv}$. "Ransom"), cowpea, hyacinth bean (Lablab purpureus), and pigeon pea (C. cajan). Using sandy loam soil collected from a plot where winged bean was previously grown, Iruthayathas and Herath (1981) showed that nodulation could begin as early as the second week after planting. Nodule distribution in accession from Indonesia (LBNC3, LBNC1), Nigeria (TPt2), PNG (UPS122), and Sri Lanka (SLS1, SLS6), was uniform across the rooting system, although with a higher number in the $30-60 \mathrm{~mm}$ root-zone, and a sharp decrease below $90 \mathrm{~mm}$, probably due to decreasing aerobic conditions. However, in a follow-up experiment with four of the previous accessions, nodule distribution was influenced by the strain of Rhizobium, with one in particular (SRI-1, the only one isolated from a winged bean field in Sri Lanka) mostly forming nodules from $90 \mathrm{~mm}$ and below (Iruthayathas and Vlassak 1982).

Winged bean is a relatively non-selective plant capable of fixing nitrogen in association with a broad-spectrum cowpea rhizobial group as shown in a controlled environment experiment in Papua New Guinea (Elmes 1976), and in field trials in Maryland, USA, using the TPt1 accession from IITA (Hildebrand et al. 1981a). Studies using rhizobia extracted from different species and genera (e.g. Arachis, Desmodium, Dolichos, Phaseolus, Pueraria, Vigna) have further demonstrated the ability of winged bean to form nodules with a broad spectrum of strains (Ikram and Broughton 1980; Iruthayathas and Vlassak 1987). Such studies reported that some rhizobia were as effective in fixing nitrogen and enhancing winged bean plant growth as were rhizobial strains isolated from field-grown winged bean itself. It should be mentioned that Harding et al. (1978) in Puerto Rico reported significant differences in nodulation between winged bean accessions while Kumarasinghe and Kumarasinghe (Anonymous 1981) in Sri Lanka found genotypic 
differences not only in nodulation but in symbiotic effectiveness and nitrogen fixation. This was followed up by Iruthayathas et al. (1985) who classified UPS31, UPS45, UPS121, UPS122 (PNG), SLS6 (Sri Lanka), and TPt8 (IITA) as relatively low nodulating (as fresh nodule weight) $\mathrm{N}_{2}$ fixing (as $\mathrm{C}_{2} \mathrm{H}_{2}$ reduction assay) accessions, while LBNC1, SLS44, TPt1 and THAI25-01 (respectively, from Indonesia, Sri Lanka, IITA, Thailand) were classified as relatively high ones. The reported variability in nodulation and nitrogenfixation activity could be a significant advantage for future breeding programmes, aiming to study and to develop improved winged bean varieties for mixed agricultural systems. A better characterisation of the relatively "low" nodulation and $\mathrm{N}$-fixing accessions might reveal individuals that are able to use more efficiently the fixed nitrogen, which could be combined with high fixation accessions through breeding. On a molecular level, the identification of specific targets for improving nodulation could start from the reported Kunitz protease inhibitor exclusively localised in senescent nodule cells in winged bean (Manen et al. 1991). Delays in the expression of this protein, potentially involved in the pathway towards nodule senescence, could lead to prolonged life of nodules in winged bean, to support nitrogen demand even during seed late developmental stages. Such an opportunity is investigated also in soybean (van Wyk et al. 2014; Yuan et al. 2016) and Medicago truncatula (Sheokand et al. 2005).

Another breeding target to improve winged bean nodulation could be through seed coat colour. In an assessment of $\gamma$-radiation $\mathrm{M}_{4}$ mutants from UPS122 and cv Kade 6/16, it was reported that that lighter seed coat colour was associated with increased nodules per plant, likely due to the alterations in flavonoid biosynthetic pathways that could influence nod genes expression during symbiotic initiation between plant and rhizobia bacteria (Klu and Kumaga 1999). Similar observations have been made in common bean (Hungria et al. 1991; Hungria and Phillips 1993) and other species (Mandal et al. 2010).

Nitrogen fixation in winged bean is comparable to other ureide-transporting legumes such as cowpea (Vigna unguiculata), Desmodium (D. intortum), Siratro (Macroptilium atropurpureum) and soybean (Pate et al. 1980; Yoneyama et al. 1986). As demonstrated by Hildebrand et al. (1981), a high nitrate treatment (15 mM solution) suppressed all nodulation in winged bean and also in a commercial soybean cultivar (cv Williams). The biomass of all aboveground parts was greater in the high nitrate treatment but, not surprisingly, the increase was greater in the soybean than in the winged bean accessions. At the low nitrate level $(0.75 \mathrm{mM}$ solution), nitrogen fixation per unit nodule mass, as measured by acetylene reduction, was significantly higher in one PNG winged bean accession (introduced to U.S. as "IL13") than in the soybean or the other two winged bean accessions.
Nitrate reductase level in leaves was significantly higher in all winged bean than in the soybean and higher for all in the high nitrate treatment than in the low one. All winged bean accessions were significantly higher than the soybean cultivar for leaf and stem protein content in both treatments, but in the high nitrate treatment total nitrogen accumulation (including non-protein nitrogen) per plant was higher in the commercial soybean cultivar. This might be due to the selection of soybean individuals in high-input conditions, where higher inorganic fertilizer uptake could have been directly or indirectly selected.

Given the nitrogen fixation capability of winged bean, a few attempts have been made to test its potential in agricultural systems. In an experiment conducted in Kentucky $\left(37^{\circ} \mathrm{N}\right)$ intercropping at high planting density with maize led to lower grain yield for the latter, while increasing total biomass and $\mathrm{N}$ yield per hectare (Hikam et al. 1991, 1992). More encouraging results were shown in crop rotation experiments in pots, by comparing winged bean to common bean, cowpea (Vigna unguiculata), and mung bean (V. radiata). Winged bean was found to provide an equivalent of 4 to $8 \mathrm{~g} / \mathrm{m}^{2}$ of $\mathrm{N}$ fertilizer, and to improve the most $\mathrm{N}$-uptake, $\mathrm{N}$-recovery efficiency, and $\mathrm{N}$-agronomic efficiency compared to the other legumes. Overall, the yield of rice after winged bean was similar to the rice yield after fallowing with additional $8 \mathrm{~g} / \mathrm{m}^{2}$ of $\mathrm{N}$ fertilizer (Rahman et al. 2014). Such results were further supported by studies on dry matter and nitrogen accumulation and partitioning in Sri Lanka (accession SLS40). With a planting density of 37,000 plants/ha, the authors reported an estimated $202 \mathrm{~kg} / \mathrm{ha}$ of $\mathrm{N}$ available as green manure, after mature seeds were harvested (Weil and Belmont 1991). Perhaps inspired by these results, Anugroho and colleagues (2010) compared winged bean (P. tetragonolobus (L.) DC. cv Urizun) to velvet bean (Mucuna pruriens), as a common cover crop (Buckles 1995; Mupangwa et al. 2017). The authors found the first to have a significantly higher $\mathrm{N}$ concentration and uptake, and lower $\mathrm{C} / \mathrm{N}$ ratio, meaning that winged bean could potentially be an optimal substitute to velvet bean as green manure (Anugroho et al. 2010). Differently, Bourke (1975) tested winged bean as a cover crop alongside 22 other legume species over a period of 3 years in Keravat (Papua New Guinea). He concluded that winged bean did not produce good ground cover or much top growth and that it was not suitable as a cover crop in Papua New Guinea. However, it is important to emphasise that the varieties Bourke used in this study were likely originated from PNG, and that these varieties have been in general recognised to have more restricted vegetative growth than germplasm originating from Southeast Asia (see for example Thompson and Haryono 1980), to which for example the cv. Urizun used by Anugroho and colleagues belongs (see "Effects of daylength and temperature on reproductive development" section). Based on this, 
winged bean as a cover crop is likely to yield better results by selecting material from Indonesia, Malaysia, or from the tuber-producing areas of Myanmar.

\section{Past breeding}

The first successful controlled crosses were conducted by Erskine and Khan (1977), using the crossing technique previously developed by Erskine and Bala (1976). The authors studied the inheritance of five qualitative traits based on two crosses from three PNG pure lines (UPS31, 4F1054, 4F1061). Within those crosses, purple colour was dominant over green for stem colour, calyx colour, pod wing, and pod specks. A single-gene mechanism was proposed for the inheritance of each of these traits, as well as for dominance of rectangular over flat pod shape. Moreover, between the genes controlling stem colour and calyx colour, and between pod wing colour and pod specks, they detected chromosomal linkage. Erskine and colleagues set out the first structured crossing programme to study the inheritance of quantitative traits in winged bean, using a partial diallel cross design between five well-studied PNG accessions (UPS81, UPS66, UPS89, UPS121 and UPS122), one Indonesian accession from Java (UPS132), and a single plant selection from TPt1 (relabelled as UPS132) (Anonymous 1980; Erskine 1981a). $\mathrm{F}_{1}$ plants along with their parents were evaluated at Port Moresby (PNG) in the wet season, and $\mathrm{F}_{2}$ arrays with parents in the following dry season. Initial analysis focused on seed yield, which indicated significant additive and dominance gene effects, with positive heterosis over the mid-parent mean across the $21 \mathrm{~F}_{1}$ families (averaging 25.6\%) (Erskine 1981a). Pod number per plant, rather than seed number per pod or mean seed weight, was the primary determinant of this heterosis. Narrow-sense heritability, determined from mid-parent $/ F_{1}$ and from $F_{1} / F_{2}$ correlations, was significantly high (0.69 and 0.56, respectively) for seed yield. This suggested that significant gains for this trait would be possible, in that environment, through judicious choice of parent accessions followed by effective selection. Narrow-sense heritability calculated from inter-generational correlations for several characters contributing to the determination of seed yield (namely, leaf-area index; pod number per plant; pod length and seed number/pod; 100-seed weight) were also significant and high. Interestingly, in the diallel analysis of yield of green vegetable pods harvested every 5 days over 9 weeks in a separate Port Moresby experiment with the same set of parents and their $\mathrm{F}_{2}$ populations, Erskine and Kesavan (1982) found both heterosis above parental means and narrow-sense heritability to be non-significant, along with non-significant differences in number of pods per plant. The authors suggested the predominance of environmental and non-additive gene components in the determination of final green pod yield. On the other hand, there were large differences between populations in measured pod characters (length, width, weight), a result similar to that reported by Jalani et al. (1983) in $\mathrm{F}_{1} \mathrm{~s}$ from a similar set of crosses. Improvements in vegetable pod yield could be achieved through indirect selection for these pod characteristics. However, the studies did not elucidate differences in some of the plant architecture traits (e.g. branch number, or raceme number per plant) that could contribute to differences in pod yield between populations and should be considered in future selection.

For another important qualitative character, days to first flower (DAP), Erskine analysed the $\mathrm{F}_{1}$ generation planted out in the long daylengths of December ( $13 \mathrm{~h}$ photoperiod). The seven parental accessions ranged from 44 to 80 DAS, and narrow-sense heritability based on the correlation with their $F_{1}$ arrays was significant and high (0.68). However, in the evaluation of the $F_{2}$ generation, planted out in the short daylengths of the following July ( $12 \mathrm{~h}$ photoperiod), flowering date among parents had a much smaller range from 46 to 51 DAS, and the narrow-sense heritability was zero. High environmental and genotype $\mathrm{x}$ environment effects for number of days to first flower was also encountered in a partial diallel involving a similar set of eight parental lines in the sub-tropical latitudes of Perth, Western Australia. There, parental means ranged widely from 109 to 194 DAP when planted on 30 October (in the increasing day lengths of mid-spring), but the narrow-sense heritability for days to flower estimated at 0.17 , did not significantly differ from zero (Eagleton 1983). The data once again showed the variation in response to changing growing conditions among germplasm, and the effect of daylength on modulating days to first flower. Unfortunately, ambient factors air and soil temperature (see "Effects of daylength and temperature on reproductive development" section) was not recorded, limiting the interpretation of this results.

Another very important determinant of agronomic performance and manageability of winged bean is plant growth habit. In a germplasm evaluation screen in Serdang (Malaysia), carried out on 147 accessions from several countries in the traditional winged bean growing centres, evaluated for forty-seven characters, the most important character apart from number of days to first flower that distinguished Highland Papua New Guinea accessions as a group from lowland South and Southeast Asian accessions was the number of primary branches (NPB) in the first ten nodes (Eagleton et al. 1985). The diallel analysis referred to above involving one-way crosses between eight representative parent accessions estimated narrow-sense heritability for NPB based on parent $/ F_{1}$ array correlation in the Perth environment to be 0.65 . Furthermore, the correlation between accession means determined in Malaysia and Perth for this character was 0.90 , and for $F_{1}$ means it was 0.93 , supporting the hypothesis of minimal influence of environmental differences 
on the expression of this trait. The analysis indicated that apart from a significant additive genetic component for this character there are dominance effects, predominantly unidirectional, favouring high branch number over low branch number. It is possible that this character is determined by a few gene loci only.

Still in PNG, one preliminary study focused specifically at the genetic control of tuberisation in winged bean. Stephenson and colleagues crossed a tuberous PNG accession (UPS122) with another PNG accession (UPS31) which was found to be a poor producer of tubers (Anonymous 1980; Stephenson et al. 1979). They compared the $\mathrm{F}_{1}, \mathrm{~F}_{2}$, and first backcross generations (BC1 and $\mathrm{BC} 2$ ) in four replicated blocks at the lowland location of Waigani (Port Moresby, PNG), a sub-optimal location for tuber production. The plots were trellised and reproductively pruned to encourage tuber bulking up. Analysis indicated that additive genetic variance for root and tuber yield was greater than either dominance or environmental variance (i.e. among the four replicate blocks). Narrow-sense heritability of root and tuber yield, number of tubers per plant, and haulm yield were $0.45,0.64$, and 0.64 , respectively. Haulm yield of the $F_{1}$ had exceeded that of the better parent UPS122, and across all plots highly correlated with root and tuber yield. To date, there has been no similar study published in the international literature concerning the genetic control of tuber yield in central Myanmar, another traditional location of winged bean tuber production.

The genetic mechanisms controlling nodulation and nitrogen fixation has received some attention from researchers as well. In crosses between TPt1 (IITA) and the relatively poor nodulator UPS122 (PNG), Iruthayathas et al. (1985) analysed the extent of host genetic determination of nodulation and nitrogen fixation, by partitioning variance for these two characters among parental, $\mathrm{F}_{1}, \mathrm{~F}_{2}$ populations. Nodulation showed low broad-sense heritability (0.25), but there was no non-allelic interaction, and additive effects were the largest component of genetic variance. Nonetheless, the high environmental effect on variance would imply that genetic advance towards enhanced nodulation could be made in late generations of the progeny of this cross. Differently, the environmental effect was lower for nitrogen fixation (broad-sense heritability 0.48), and again most of it appeared of additive origin, suggesting substantial genetic advance could be attained in generations as early as $F_{2}$. Genetic studies of host resistance to certain diseases that can limit winged bean have also been reported in the literature. Aminah Lubis and Sastrapradja (Anonymous 1981) produced evidence from hybridisation studies indicating that resistance to the false rust disease Synchytrium psophocarpi in some accessions from West Java is conferred by two gene loci, at which alleles for susceptibility are dominant to alleles for resistance. Thompson and Haryono (1979) confirmed the presence of resistance to $S$. psophocarpi in the West Javanese accessions and also reported on the occurrence of resistance in Javanese germplasm to the disease yellow mosaic virus. Any controlled hybridisation for germplasm improvement in winged bean should take into account the outcome of controlled crosses carried out by Jalani et al. (1983). By analysing 6 crosses in a full diallel design, they found evidence of maternal and paternal effect within each cross on pod length, seed number per pod, and 100-seed weight.

\section{The genomics era}

Initial analysis of genetic diversity and population structures relied on phenotypic traits known to be controlled by single genes (Erskine and Khan 1977). Analysing three such phenotypic markers, Erskine and Khan (1980) analysed the structure of the winged bean population upon samples collected across multiple locations in highland PNG. Eventually, they were able to support the idea of winged bean being a self-fertilising species, with poor gene-flow even between proximate locations. Subsequent studies, on much broader germplasm from wider geographical range, confirmed the basic picture of a cleistogamous species comprising landraces of predominantly inbred lines with a low level of cross-pollination but suggested a more complex population structure for the species as a whole. PNG highland accessions on the one hand, Indonesian and Burmese accessions on the other, appear to be more highly domesticated offshoots of a vegetable species that through most of its distribution is a useful, but low-maintenance, sprawling vegetable crop, subject to little purpose-driven selection pressure (Sastrapradja and Aminah Lubis 1975; Thompson and Haryono 1980; Anonymous 1981; Chandel et al. 1984). Such studies begun to evaluate winged bean diversity and population structure of germplasm collection based on phenotypic observations: knowledge on the genetic diversity is indeed important for selecting material to include in breeding programmes that is as diverse as possible. However, it is only with the advent of molecular technologies that researchers could start looking at polymorphisms in DNA sequences: independently from the subjective recording of a phenotype, and free from environmental effects. We had to wait till 2013 to have the first study of this kind in winged bean, when Mohanty et al. (2013) analysed DNA of 24 accessions from at least four sources including India, Nigeria, and Thailand, through 13 Random Amplification of Polymorphic DNA (RAPD) and 7 Inter Simple Sequence Repeat (ISSR) molecular markers. They found ISSR amplification to be the more effective among the two approaches, but by combining the two sets of data they obtained a total of 167 clearly 
identifiable markers, of which 138 (83\%) proved to be polymorphic across the range of the screened accessions. Cluster analysis applied to the cumulative data from the two sets of primers, grouped the 24 accessions into seven clusters that the authors judged not to be "in congruence with their geographic affiliations". Later, Chen et al. (2015) worked on a different set of 45 winged bean accessions from eight countries (PNG, Indonesia, Thailand, Nigeria, Colombia, Sri Lanka, Costa Rica, and China), using a set of five ISSR markers. These latter generated 67 identifiable marker fragments of which only $44(65.7 \%)$ revealed polymorphism. Despite the lower degree of polymorphism compared to Mohanty and colleagues' findings, their four groups derived from cluster analysis led to the same conclusions: there was no consensus between genetic distance and geographical origin of the accessions.

A different approach to developing useful genomic markers for genetic studies is one which focusses on RNA rather than DNA nucleotide sequences. Genic SSR, for example, have been useful in genetic diversity analysis, as well as in linkage analysis for applying marker assisted selection (MAS) in breeding (Varshney et al. 2005). The first attempt in this direction resulted in the sequencing, assembly, and annotation of transcriptomes from four "orphan" (i.e. underutilised) crops, among which figured the winged bean accession TPt1, also identified as Ibadan Local-1 (Chapman 2015). The second transcriptomic analysis sequenced, annotated, and compared scored Simple Sequence Repeat (SSR) markers from two Sri Lankan accessions, one of which was collected in the field and the other maintained in the USDA seed bank since 1984 (Vatanparast et al. 2016). When comparing the transcripts obtained from these two Sri Lankan accessions, the authors found a high degree of similarity between the two [less than 200 Single Nucleotide Polymorphisms (SNPs)]. However, when they compared the combined SSR library of the Sri Lankan accessions with that of Chapman's TPt1, they identified 5190 SNPs, showing a more distant genetic relationship. In 2017, two additional studies led to publication of transcriptomes. Singh and colleagues developed data from two accessions held in India differing for tannin contents. The expression analysis led to the isolation of candidate genes involved in phenylpropanoid pathway, and the differential expression level were validated through real time-PCR (Singh et al. 2017). Later on, another study developed genic SSR markers from transcriptome data generated from a Malaysian accession. From this, the authors went on to validate 18 SSR markers upon nine genotypes originated from five countries (Malaysia, Bangladesh, Sri Lanka, Indonesia, and PNG) (Wong et al. 2017). Yang et al. (2018) used five of these markers to screen 53 accessions from IITA, U.S. Department of Agriculture (USDA), and the National Agriculture and Food Research Organization (NARO, Japan) genebanks. Principal Coordinates
Analysis (PCoA) results indicated no clustering by country of origin, and the population structure suggested four subpopulations, each comprising of accessions from multiple countries, spanning in some case between South America, Asia, and Africa (Yang et al. 2018). Overall, these findings were in agreement with previous genetic analysis through ISSR and RAPD markers, in which molecular markers-based grouping did not agree with geographical origins (Mohanty et al. 2013; Chen et al. 2015). The authors, given also the suggested presence of admixture from clusters obtained through STRUCTURE analysis, suggested the possibility of crossing between genetic material coming from different origins, probably thanks to transport/sharing of seeds. Regarding these findings, two things are worth mentioning: the first one is the international trial organised by the ICDUP (see "Synthesis of past research" section), which did promote seed sharing, especially from South East Asian countries and PNG. Following on from this, the presence of accessions collected in South American countries (e.g. Costa Rica and Colombia), raises questions, given that winged bean had never been an endogenous crop. Accessions deposited in international collections (e.g. USDA) and collected from Colombia, carry indeed the "UPS" label, the trademark of PNG material used in the past studies. The second source of bias in grouping by geographical origin could be the incorrect relabelling of the accessions used in studies. There are, indeed, clues spread across papers and reports about the true origin of accessions re-labelled by different institutes. An immediate, and rather important, example is the TPt 1 accession deposited at the IITA genebank (Nigeria). Also known as Ibadan-Local 1 and usually referred to as from Nigeria, this may well have originated in PNG (see Erskine and Kesavan (1982) citing K. O. Rachie), and was also relabelled UPS132 by the same Erskine (1981).

Considering the uncertainty that has arisen about the declared origins of winged bean accessions now held in various genebanks around the world, it would make sense to genotype deposited accessions and retrieved germplasm, without relying particularly on the declared geographical origin or assumptions based on phenotypic characterisation. In this context, high-throughput genotyping by sequencing $(\mathrm{GbS})$ technologies could aid in obtaining a finer picture of the germplasm currently held. This would lead to more reliable identification of regions where additional diversity could be mined, and to more efficient selection of truly diverse material for phenotyping and breeding.

\section{Photothermal sensitivity}

For winged bean to fulfil its potential, several constraints, which limit its productivity and hence its wider adoption as a crop, must be tackled. The first is its photothermal 
sensitivity, given the effects that this has on its development and final yield, which also limits the potential expansion of winged bean cultivation areas. The combined effect of temperature and daylength on flowering is not unique to winged bean. In a well-known short-day legume, soybean, there are at least 10 loci controlling flower initiation, and for most of them, recessive alleles confer the observed degrees of photoperiod insensitivity (Xu et al. 2013b; Zhai et al. 2014; Weller and Ortega 2015; Zhang et al. 2016). Genetic pathways underlying mechanisms such as flowering are likely to be conserved across taxa (Hecht 2005; Kwak et al. 2008; Zhang et al. 2016), making it possible to harness information from a model species, such as soybean, and transfer it to a lessresearched species, such as winged bean. An approach could be the development of linkage maps from mapping populations, followed by discovery of syntenic regions of the genomes of well characterised species, and identification of candidate genes for traits of interest. Such an approach has been implemented to identify flowering QTLs in faba bean (Vicia faba) (Catt et al. 2017). The advantage of generating mapping populations would also be the concurrent study and exploitation of the natural variation for the trait of interest. Luckily, such variation has been reported in winged bean, in particular between sets of germplasms coming from different regions, such as Papua New Guinea and South East Asia (Thompson and Haryono 1980; Erskine 1981b; Eagleton 1983). The above-mentioned experiments under subtropical conditions in Japan (Abe and Nakamura 1983; Abe et al. 1988; Nakamura and Abe 1989) and elsewhere would suggest the presence of genetic variation necessary to generate winged bean varieties that are less sensitive, or even neutral, to photothermal regulation. This would expand the current geographical boundaries in which this legume could be cultivated, towards higher latitudes characterised by warm temperatures in the spring to autumn months, and establish it as a crop in subtropical areas.

\section{Winged bean: a perspective}

Winged bean has significant potential to contribute to food and nutritional security globally. Its ability to produce green pods, edible leaves, and tuberous roots makes it a useful horticultural crop. Its mature seeds are a good source of protein and other nutrients, making winged bean a potential pulse crop for large-scale production in the humid and sub-humid tropics (NAS 1975b; Gross 1983; Kadam et al. 1984; Misra and Misra 1985; Lepcha et al. 2017). The nutritional profile of these edible parts could play a major role in diet improvement of people especially in areas where major vegetable crops require high-inputs, limiting consumers' access to vegetables. Furthermore, production of mature seeds could help reduce the demand and dependence on major crops such as soybean for production of value-added products like tofu, and plant-based milk. In low-input systems, there is potential to grow winged bean on a relatively wide range of soils, because of its propensity to nodulate with different Rhizobia and its efficient nitrogen-fixation activity. Additionally, winged bean's ability to store high concentrations of $\mathrm{N}$ in its biomass makes it possible to incorporate the crop into different cropping systems such as rotation intercropping and as a cover crop. All these aspects support further research investment into winged bean, and its wider inclusion in agricultural systems.

\section{Growth habit and plant architecture}

Winged bean (see supplementary materials; figures A.1 to A.5) has intertwining vines that grow indeterminately, with a variable number of lateral branches (NAS 1975b; Khan and Erskine 1978; Eagleton 1983; Schiavinato and Válio 1996b). Until now, all published reports indicate that winged bean has a climbing growth habit, and naturally occurring determinate bush-type growth forms have not been observed in the species. A few investigations aimed at identify influences on plant structure have been published, by testing different physical supports and eventually concluding that trellis was needed in order to promote lateral branching and boost pod production (NAS 1975b; Anonymous 1978, 1981; Nangju and Baudoin 1979; Schiavinato and Válio 1996b). The number of lateral branches, as reported earlier (Eagleton et al. 1985), showed a significant degree of variation among germplasm from different areas, and could be a major target for obtaining desired plant architecture ideotypes in winged bean. However, there is still not a clear investigation focused on the growth, development, and inter-relationship among winged bean plant architecture traits (e.g. lateral branching, stem length, node number and internode length, leaves per plant), neither has there been research on how each of these influence yield-related traits (e.g. pods per plant).

In order to obtain dwarf or determinate winged bean cultivars, several researchers have attempted to use mutagenesis (Khan and Brock 1975; Jalani 1976; Jugran et al. 1986; Klu 1996; Quan et al. 2011; Chethan and Chikkadevaiah 2014). Unfortunately, from the published literature there is no clear evidence on whether such attempts have succeeded in producing either of the desired phenotypes.

Perhaps, TILLING (targeting induced local lesions in genomes) or ecoTILLING are possible approaches to obtain determinate growth phenotypes, although this method requires sequence information of target genes. The genomic basis of a determinate shoot apex meristems has been uncovered in other leguminous crops; for example, soybean (Tian et al. 2010), chickpea (Hegde 2011), common bean (Kwak 
et al. 2012; Repinski et al. 2012), and cowpea (Dhanasekar and Reddy 2015), where the determinate shoot phenotypes are reported to be related to mutations in genes orthologous with the A. thaliana TERMINAL FLOWERI (TFL1) genes. Such information could be used to identify candidate genes involved in the same mechanism in winged bean and to define the target for TILLING methods. Another approach could be again the use of the conserved syntenic mapping approach for identification of QTL underlying morphological traits, as recently demonstrated in another underutilised species, bambara groundnut (Vigna subterranea) (Ho et al. 2017).

Alternatively, a more classical approach could focus on accessions grown predominantly for tuberous production, rather than for pods and seeds (NAS 1975b; Khan et al. 1977; Khan and Erskine 1978; Eagleton 1999), which could have undergone an initial selective pressure. Phenotypic screening for naturally occurring determinate growth habit could concentrate efforts on the winged bean tuber production fields of Central Myanmar, where crops are routinely grown without trellising, on a scale up to a hectare (Eagleton, personal communication). Exploration of these tuber growing areas for variation in growth habit and other useful variants is long overdue.

\section{Mature seeds consumption}

Mature winged bean seeds (see supplementary materials; figures S.1) contain on average around 15-18\% fat and 30-37\% crude protein, and a favourable amino acid and micronutrient composition (Černý et al. 1971; Claydon 1975; Gillespie and Blagrove 1978; Garcia and Palmer 1980; Hildebrand et al. 1981b; Gross 1983; Kadam et al. 1984). Protein content and fatty acid profiles compare favourably with soybean and chickpea (Cicer arietinum) (Claydon 1975; Kadam et al. 1984), and peanut (Garcia et al. 1979; Ekpenyong and Borchers 1980a; Garcia and Palmer 1980). A comprehensive assessment of the nutritional properties of winged bean seeds and the other edible parts, along with comparisons with other leguminous crops, have being adequately reviewed elsewhere (see for example Claydon 1975, 1983; Kailasapathy and Sandrasegaram 1983; Kadam et al. 1984; Kantha and Erdman 1984; Kailasapathy and Macneil 1985; Prakash et al. 1991; Lepcha et al. 2017). However, for mature seeds, two points should be mentioned. First, a hard coat that adheres tightly to the cotyledons could hamper cookability and digestion of winged bean mature seeds. Henry and colleagues studied cooking time across tropical legumes, where winged bean required almost double the time $(220 \mathrm{~min})$ for cooking compared to kidney beans ( $P$. vulgaris) (time to texture judged acceptable by Sri Lankan housewives) (Henry et al. 1985). It must be pointed out, though, that the authors analysed only one cultivar ("Chimbu" from PNG) against legumes that have historically been used as pulses (e.g. pigeon pea, black lentils, kidney bean and soybean). Furthermore, soybean, a pulse widely consumed for its seeds and a well-researched crop with improved varieties, took only $10 \mathrm{~min}$ less to be cooked in the same experiment (210 min) (Henry et al. 1985). Clearly, cooking traits and especially the hard-to-cook phenomenon in winged bean is an important aspect that effects consumer acceptability and is worth researching. Indeed, the development of easy-to-cook varieties of winged bean without compromising on its nutritional content should be one of the breeding objectives in any future winged bean breeding programme.

The second point concerns anti-nutritional factors in the winged bean seed, where decreased concentration remains a major goal for improving net protein utilisation. A significant step forward in this direction is the identification of genes involved in tannin content (Singh et al. 2017), as well as identification of other anti-nutritional factors (Gillespie and Blagrove 1978; Kortt 1983; Umemoto et al. 1992; Habu et al. 1996, 1997; Vatanparast et al. 2016). Cooking methods have also being investigated, with autoclaving or boiling being the most promising for seed processing and safe consumption, while maintaining high nutritive value and taste (Černý and Addy 1973; Kadam et al. 1987). Screening for thinner seed coat might bring benefits, given the role it has in water uptake during soaking. Variation in water uptake during soaking, recorded across different accessions, could be harnessed for this purpose in breeding programmes on winged bean seed coat improvement (Anonymous 1980; Ekpenyong and Borchers 1980b; Henry et al. 1985; Deshpande and Cheryan 1986; Sambudi and Buckle 1991).

\section{Future directions}

Despite the latest phylogenetic analysis by Yang et al. (2018), the centre of origin of winged bean remains a matter that requires further investigations. Research efforts in this direction, based on larger collections of the cultivated P. tetragonolobus and related Psophocarpus species, could yield a clearer picture of the taxonomy, origin and evolution of winged bean, and allow for a strategic exploitation of the resources for future improvement. Such analysis ought to be carried out on germplasm (or subsets of) currently held in different countries and institutes. The declared geographical origin for each accession should be treated carefully, looking at codes such as "UPS" (usually from PNG) or "SLS" (usually from Sri Lanka), and taking it as indication, rather than certainty.

Renewed efforts could mirror, to an extent, what the dedicated international centre did back during the $70 \mathrm{~s}$ and $80 \mathrm{~s}$, by creating a panel of common accessions for phenotypic 
screening, and for development of populations with shared molecular information. Such steps are critical also in the development of mapping populations, linkage mapping, and Genome Wide Association Studies (GWAS) for trait discovery, as shown in soybean (Li et al. 2018), chickpea (Bajaj et al. 2016; Saeed and Darvishzadeh 2017), mung bean (Noble et al. 2018), and common bean (Tock et al. 2017). This would allow us also to combine phenotypic and genetic data across different environments and assess the degree of adaptability and plasticity of winged bean. Photoperiod sensitivity is likely to demand the most out of these combined efforts, especially for the required screening of natural or mutated individuals and the identification of the molecular basis of insensitive phenotypes. For all kind of screenings, an important component would be the development of common descriptors in order to phenotype the analysed germplasm, perhaps starting by updating those utilised during earlier studies (IBPGR 1982), and currently available at https://www.bioversityinternational.org/e-library/publicatio ns/detail/winged-bean-descriptors-revised/.

Winged bean, as for any other crop, is grown in multiple contexts and its growth and development have implications for farming practices and costs. It is therefore natural to call for the design of ideotypes that fit into such contexts, through studies that clarify the effect of the plant architecture on yield, and the best trade-offs between them (see Fig. 1 for potential breeding targets). To stress this concept, winged bean can be cultivated on a variety of supporting structures (e.g. strings, trellises or single stalks), as well as on the ground without any support. Any desired alteration to the winged bean plant architecture and its potential effects on developmental processes would depend on the desired product or final farming purposes (for example for pods, seeds, tubers production) and the distinction between supported and unsupported cultivation methods. It should also be noted that individuals with longer growing cycles and extended flowering period are desirable in certain conditions (e.g. as a cover crop where biomass is the objective) and so are early maturing types, e.g. for seed production. Moreover, an extended flowering period might be preferred by smallscale farmers and for domestic use, as this ensures a continuous source of food and products to sell in local markets over an extended period. Post-harvest research could have a role here, as well as in preserving green pods and tubers for larger distribution areas, but unfortunately, no research has been conducted so far on this. Figure 1 presents possible breeding targets for winged bean.

Perhaps the least explored area in the past research is the ability of winged bean to tolerate abiotic stresses, like drought, salinity, or waterlogging. After his investigations,

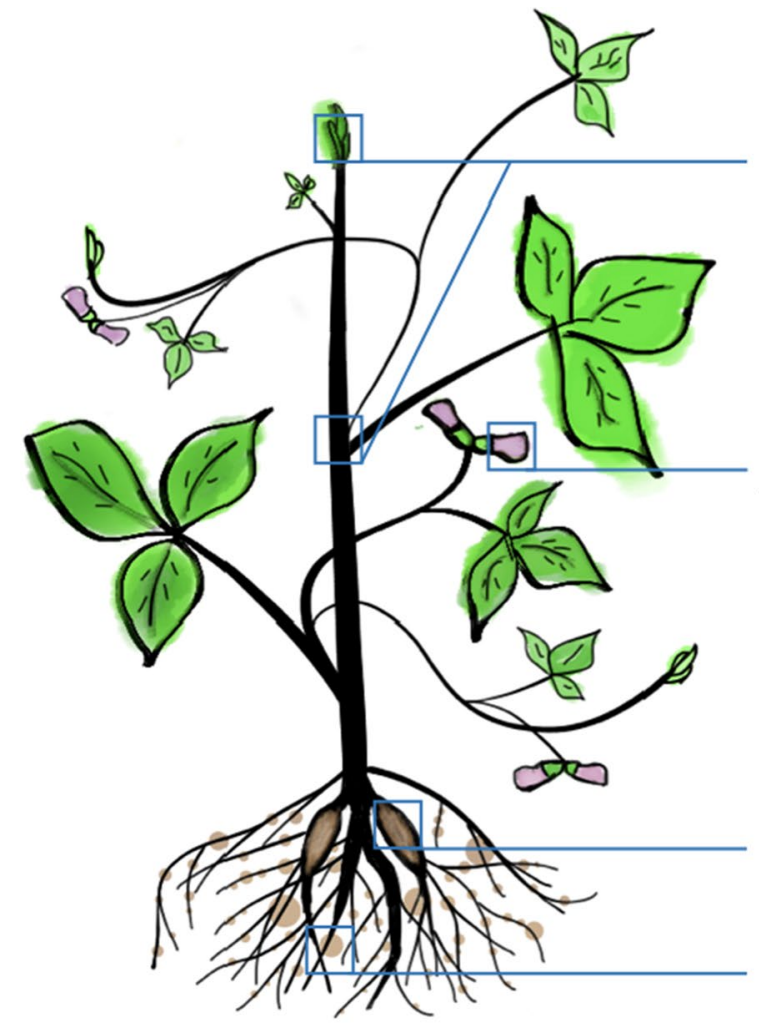

Plant architecture impact on productivity, ideotypes that fit different cultivation practices and growing conditions

Nutritional and texture improvement, synchronised harvesting, post-harvest technology

Photothermal insensitivity, assessment of cross-pollination

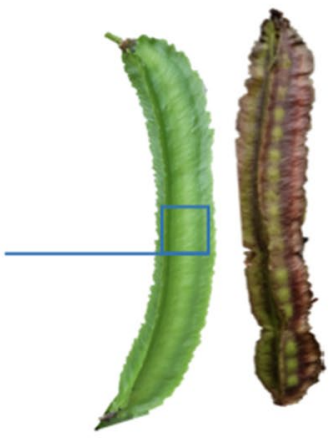

Seed coat properties, anti-nutritional factors, improved quality for added-value products

Tubers productivity and nutritional improvement

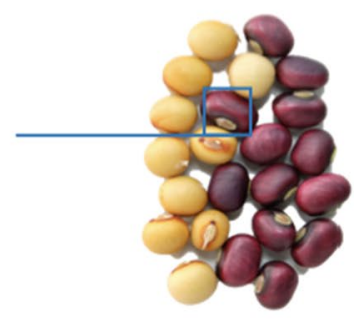

Nodulation and $\mathrm{N}$-fixation activity under stressful conditions, low-input systems integration

Fig. 1 Possible breeding targets for winged bean improvement programmes 
Karikari suggested a list of characters for potential identification of drought tolerant individuals in winged bean, which included, among others, number and weight of nodules per plant and stem thickness (Karikari 1978). Another study investigated the effect of salt stress on nitrogenase activity, which showed activity to be significantly more hampered in winged bean than in soybean, although winged bean had higher plant $\mathrm{N}$, and less foliage injury (Weil and Khalil 1986). The authors concluded that winged bean, here represented by just one accession commonly grown in Sri Lanka (SLS47), was similar to the soybean cv. "Lee", considered to be one of the most salt tolerant soybean cultivar and used, among others, for the discovery of the $\mathrm{Ncl}$ gene involved in this trait (Weil and Khalil 1986; Do et al. 2016). Such findings would encourage further research to explore salt tolerance attributes of winged bean. In addition to droughttolerance and photothermal sensitivity, the ability of winged bean to withstand abiotic stresses will not only determine the extent of adoption beyond its current areas of cultivation but will also determine its position in low-input agricultural systems.

Lessons learned from past research experiences are a key component of the toolkit required to develop winged bean into 'a one-stalk supermarket'. Although the plurality of winged bean edible parts offers the opportunities for breeders to develop this crop in different ways for commercial purposes, research should not lose sight of the traditional modes of consumption. Winged bean is more likely to be a horticultural crop first: immature pods, tubers, green seeds, and leaves should be the main target for increased productivity and nutritional quality.

The mature seed's potential could be realised by focusing on improving cookability and reducing anti-nutritional factors, while gaining more economic value if introduced into pipelines to produce value-added products. Food technologists have already started to investigate ways to adapt processing methods already used for crops like soybean, to generate alternative food products with a variety of nutritional profiles and taste, like tofu, tempeh, and bean milk (Omachi et al. 1983; Kantha et al. 1983; Prakash et al. 1987; Jinsong Yang and Haisheng Tan 2011). This would increase the appeal of winged bean seed products, and potentially introduce it to larger global markets. Creation of cultivars with improved palatability of the vegetable pods could benefit from reduction of the fibre content and conformation of the pod walls. However, this would need to be carefully evaluated because, there is no guarantee that reducing pod fibre content would improve eating quality. Modifying the pod wall could also influence the extent of seed loss through pod-shattering (Koinange et al. 1996).

Unfortunately, no relevant information is available about national production of winged bean. Being mainly cultivated on small scale, in home gardens, and sold at local markets, makes it difficult to have an actual idea of the extent of cultivated area, production, and market price, an issue in common with other minor crop species (Khoury et al. 2014). This lack of information makes it harder to include crops like winged bean into a more comprehensive assessment of the diversity of national food production systems, and to advocate for policies and research funding schemes to improve such sources of food and income. We hope that, as for other crops, data will be collected for winged bean, where its presence in local markets is a significant source of food and income. Moreover, studies comparing the growth and yield performance of winged bean with other leguminous crops should be conducted, to define contexts where winged bean could efficiently be introduced as an alternative crop without having decreased food production.

Finally, for the development of orphan crops such as winged bean, past research is critical and yet difficult to access first hand. For this reason, Crops For the Future (CFF) is establishing wingedbeannetwork.org, to build upon the work started with wingedbeanflyer.org by Graham Eagleton, as a platform to share the outcomes of past research, and to engage with farmers, researchers, and private companies. The aim is also to share new research results, and to promote collaborations among the different players involved in the research and cultivation of winged bean.

\section{Conclusions}

Through the declaration of the Sustainable Development Goals 2030, the United Nations has called for more efforts to end hunger, achieve food security, improve nutrition, and promote sustainable agriculture (UN 2015). There is growing data supporting the advantages of including more crops into our agricultural systems, to achieve food and nutritional security. There is a strong case for an increased utilisation of vegetables and pulses to improve, above all, human nutrition. Winged bean can be grown as both, given its edible green pods, immature seeds, tuberous roots, leaves, and mature seeds. This underutilised crop has potential beneficial traits related to its nodulation and nitrogen-fixation activity that could support low-input farming and improve soil conditions. This review has explored past findings related to the controlling mechanisms underlying traits like growth, flowering, and yield of the different edible parts of winged bean. To date, several production and plant architectural constraints remain unresolved. These include the indeterminate growth habit, photothermal sensitivity, inconsistent productivity for edible parts, anti-nutritional content of seeds, and winged bean nodulation. This review has provided some suggestions on a fresh approach to resolve these constraints.

Improvement programmes for winged bean should keep in mind the prevalent practices used in traditional regions 
of production, especially winged bean cultivation methods and ways of consumption. Research efforts should prioritise the development of high yielding cultivars of high palatability and nutritional value, with the design of ideotypes for vegetable pod and tuberous root production, currently the most important uses for winged bean. Research should also continue into the improvement of yield, nutritional value, and marketability of mature seeds. Concerted winged bean improvement programmes would require a panel of winged bean accessions to be shared among research institutes, for generating information that can be made available and shared in a coordinated manner. Regarding this, it is crucial to firstly track viable material shared or retrieved from genebanks, with a labelling system consistent across research groups, and secondly to utilise a common set of descriptors and procedures to phenotype the germplasm. Starting from this, molecular tools (GBS, RNA-Seq, GWAS) can then be used to accelerate the efforts to tackle critical traits. In such regard, the generation of winged bean mapping populations, linkage maps, and genome sequencing would boost the translation of information already developed in other crops and the dissection of traits of interest in winged bean.

Author contribution statement All authors conceived the paper. AST, GEE, and QNW analysed past literature, wrote, reviewed and edited the manuscript. WH has reviewed the manuscript and provided scientific feedback. SM and FM reviewed the manuscript, provided scientific feedback and critical comments. All authors read and approved the manuscript.

Acknowledgements The authors would like to thank Crops For the Future (CFF) and the University of Nottingham Malaysia (UNM) for financial support. The authors wish to dedicate this paper to the memory of Quin Nee Wong.

Open Access This article is distributed under the terms of the Creative Commons Attribution 4.0 International License (http://creativeco mmons.org/licenses/by/4.0/), which permits unrestricted use, distribution, and reproduction in any medium, provided you give appropriate credit to the original author(s) and the source, provide a link to the Creative Commons license, and indicate if changes were made.

\section{References}

Abe J, Nakamura H (1983) Evaluation of winged bean in Okinawa. Okinawa, Japan

Abe J, Nakamura H, Hanada T et al (1988) Response of winged bean to temperature and photoperiod at different locations distributed from the tropics to the temperate zone. Jpn Agric Res Q 21:308-313

Adhikari L, Hussain A, Rasul G (2017) Tapping the potential of neglected and underutilized food crops for sustainable nutrition security in the mountains of Pakistan and Nepal. Sustainability. https://doi.org/10.3390/su9020291

Anonymous (1978) The winged bean-papers PRESENTED at the 1st international symposium on developing the potentials of the Winged Bean (Manila, Philippines). Philippine Council for Agriculture and Resources Research, Los Banos

Anonymous (1980) The winged bean flyer (3 No.1). International Documentation Centre for the Winged Bean Agricultural Information Bank of Asia, Laguna

Anonymous (1981) The winged bean flyer (3 No.2). International Documentation Centre for the Winged Bean Agricultural Information Bank of Asia, Laguna

Anonymous (1982) The winged bean Flyer (4 No.1). International Documentation Centre for the Winged Bean Agricultural Information Bank of Asia, Laguna

Anugroho F, Kitou M, Kinjo K, Kobashigawa N (2010) Growth and nutrient accumulation of winged bean and velvet bean as cover crops in a subtropical region. Plant Prod Sci 13:360-366. https ://doi.org/10.1626/pps.13.360

Arumugan S, Perera ALT (1989) A study of the genetic architecture of some yield parameters of winged bean using model-fitting techniques. Trop Agric Res 1

Bajaj D, Srivastava R, Nath M et al (2016) EcoTILLING-based association mapping efficiently delineates functionally relevant natural allelic variants of candidate genes governing agronomic traits in chickpea. Front Plant Sci 7:450. https://doi.org/10.3389/ fpls.2016.00450

Bazile D, Pulvento C, Verniau A et al (2016) Worldwide evaluations of quinoa: preliminary results from post international year of quinoa fao projects in nine countries. Front Plant Sci 7:850. https://doi. org/10.3389/fpls.2016.00850

Bennett MD, Smith JB (1976) Nuclear DNA amounts in angiosperms. Philos Trans R Soc Lond Ser B Biol Sci 274:227-274

Bourke RM (1975) Evaluation of leguminous cover crops at Keravat, New Britain. Papua New Guinea Agric J 26:1-9

Buckles D (1995) Velvetbean: a "new" plant with a history. Econ Bot 49:13-25. https://doi.org/10.1007/BF02862271

Burkill IH (1906) Goa beans in India. Agric Ledger 4:101-114

Catt SC, Braich S, Kaur S, Paull JG (2017) QTL detection for flowering time in faba bean and the responses to ambient temperature and photoperiod. Euphytica 213:125. https://doi.org/10.1007/s1068 1-017-1910-8

Černý K, Addy HA (1973) The winged bean (Psophocarpus palustris Desv) in the treatment of kwashiorkor. Br J Nutr 29:105. https:// doi.org/10.1079/bjn19730082

Černý K, Kordylas M, Pospíšil F et al (1971) Nutritive value of the winged bean (Psophocarpus palustris Desv). Br J Nutr 26:293. https://doi.org/10.1079/bjn19710035

Chandel KPS, Pant KC, Arora RK (1984) Winged Bean in India. NBPGR Sci. Monogr. No. 8. National Bureau of Plant Genetics Resources, New Delhi, India

Chapman MA (2015) Transcriptome sequencing and marker development for four underutilized legumes. Appl Plant Sci 3:1400111. https://doi.org/10.3732/apps.1400111

Chappell MJ, LaValle LA (2011) Food security and biodiversity: can we have both? An agroecological analysis. Agric Hum Values 28:3-26. https://doi.org/10.1007/s10460-009-9251-4

Chen D, Yi X, Yang H et al (2015) Genetic diversity evaluation of winged bean (Psophocarpus tetragonolobus (L.) DC.) using inter-simple sequence repeat (ISSR). Genet Resour Crop Evol 62:823-828. https://doi.org/10.1007/s10722-015-0261-3

Chethan KG, Chikkadevaiah (2014) The effect of gamma rays on yield and yield attributes in winged bean (Psophocarpus tetragonolobus (L.) DC.) genotypes. Bioinfolet 11:953-956

Chivenge P, Mabhaudhi T, Modi AT, Mafongoya P (2015) The potential role of neglected and underutilised crop species as future 
crops under water scarce conditions in Sub-Saharan Africa. Int J Environ Res Public Health 12:5685-5711. https://doi. org/10.3390/ijerph120605685

Claydon A (1975) A review of the nutritional value of the winged bean Psophocarpus tetragonolobus (L.) DC. with special reference to Papua New Guinea. Sci New Guinea 3:103-114

Claydon A (1983) Potential of winged bean pods and their products in Papua New Guinea. Qual Plant Plant Foods Hum Nutr 32:167177. https://doi.org/10.1007/BF01091337

Deshpande SS, Cheryan M (1986) Microstructure and water uptake of phaseolus and winged beans. J Food Sci 51:1218-1223. https:// doi.org/10.1111/j.1365-2621.1986.tb13089.x

Dhanasekar P, Reddy KS (2015) A novel mutation in TFL1 homolog affecting determinacy in cowpea (Vigna unguiculata). Mol Genet Genom 290:55-65. https://doi.org/10.1007/s00438-014-0899-0

Do TD, Chen H, Hien VTT et al (2016) $N c l$ synchronously regulates $\mathrm{Na}+, \mathrm{K}+$, and $\mathrm{Cl}$-in soybean and greatly increases the grain yield in saline field conditions. Sci Rep 6:1-10. https://doi. org/10.1038/srep19147

Drinkall MJ (1978) False rust disease of the winged bean. Trop Pest Manag 24:160-166. https://doi.org/10.1080/096708778094116 05

Dwivedi SL, Lammerts van Bueren ET, Ceccarelli S et al (2017) Diversifying food systems in the pursuit of sustainable food production and healthy diets. Trends Plant Sci 22:842-856. https://doi. org/10.1016/j.tplants.2017.06.011

Eagleton GE (1983) Evaluation of genetic resources in the winged bean (Psophocarpus tetragonolobus (L.) DC.) and their utilisation in the development of cultivars for higher latitudes. University of Western Australia

Eagleton G (1999) Winged bean in Myanmar, revisted. Econ Bot 53:342-352

Eagleton GE, Sandover S (1984) Adaptation of winged bean to Kununurra clays. Dry Season 1984. Western Australia Department of Agriculture (Kununurra Regional Office)

Eagleton GE, Khan TN, Erskine W (1985) Winged bean (Psophocarpus tetragonolobus (L.) DC. In: Summerfield RJ, J. RE (eds) Grain legume crops. Collins, London, pp 624-657

Ekpenyong TE, Borchers RL (1980a) The fatty acid composition of the oil of the winged bean (Psophocarpus tetragonolobus L.) seeds. J Am Oil Chem Soc 57:147-149. https://doi.org/10.1007/ BF02673105

Ekpenyong TE, Borchers RL (1980b) Effect of cooking on the chemical composition of winged beans (Psophocarpus tetragonolobus). J Food Sci 45:1559-1560. https://doi. org/10.1111/j.1365-2621.1980.tb07562.x

Elmes RPT (1976) Cross-inoculation relationships of Psophocarpus tetragonolobus and its rhizobium with other legumes and rhizobia. Papua New Guinea Agric J 27:53-57

Endo M, Inada I, Uemoto S (1993) Studies on the adaptability of winged beans for the cultivation in cold regions. J Jpn Soc Hortic Sci 62:155-163. https://doi.org/10.2503/jjshs.62.155

Erskine W (1980) Measurements of the cross-pollination of winged bean in Papua New Guinea. SABRAO J 12:11-14

Erskine W (1981a) Inheritance of some economic characters in winged bean. In: Paper presented at the 2nd international seminar of winged bean, Colombo

Erskine W (1981b) Heritability and combining ability of vegetative and phenological characters of winged beans (Psophocarpus tetragonolobus (L) DC). J Agric Sci 96:503. https://doi. org/10.1017/s0021859600034456

Erskine W, Bala AA (1976) Crossing technique in winged bean. Trop Grain Legum Bull 6:32-35

Erskine W, Kesavan V (1982) Genetic variability in the green pod production of winged bean. J Hortic Sci 57:209-213. https://doi. org/10.1080/00221589.1982.11515042
Erskine W, Khan TN (1977) Inheritance of pigmentation and pod shape in winged bean. Euphytica 26:829-831. https://doi.org/10.1007/ BF00021714

Erskine W, Khan TN (1980) Variation within and between land races of winged bean (Psophocarpus tetragonolobus (L.) DC.). F Crop Res 3:359-364. https://doi.org/10.1016/0378-4290(80)90041-6

FAO (2010) The second report on the state of the World's plant genetic resources for food and agriculture. Food and Agriculture Organization of the United Nations, Rome

FAO (2011) The state of food insecurity: how does international price volatility affect domestic economies and food security?. Food and Agriculture Organization of the United Nations, Rome

FAO (2015) Coping with climate change-the roles of genetic resources for food and agriculture. Food and Agriculture Organization of the United Nations, Rome

Fatihah HNN, Maxted N, Rico Arce L (2012) Cladistic analysis of Psophocarpus Neck. ex DC. (Leguminosae, Papilionoideae) based on morphological characters. S Afr J Bot 83:78-88. https ://doi.org/10.1016/j.sajb.2012.07.010

Garcia VV, Palmer JK (1980) Proximate analysis of five varieties of winged beans, Psophocarpus tetragonolobus (L.) DC. Int J Food Sci Technol 15:469-476. https://doi. org/10.1111/j.1365-2621.1980.tb00965.x

Garcia VV, Palmer JK, Young RW (1979) Fatty acid composition of the oil of winged beans, Psophocarpus tetragonolobus (L.) DC. J Am Oil Chem Soc 56:931-932. https://doi.org/10.1007/BF026 74137

Gillespie J, Blagrove R (1978) Isolation and Composition of the Seed Globulins of Winged Bean, Psophocarpus tetragonolobus (L) DC. Aust J Plant Physiol 5:357. https://doi.org/10.1071/pp978 0357

Gross R (1983) Composition and protein quality of winged bean (Psophocarpus tetragonolobus). Qual Plant Plant Foods Hum Nutr 32:117-124. https://doi.org/10.1007/BF01091332

Habu Y, Peyachoknagul S, Umemoto K et al (1992) Structure and Regulated Expression of Kunitz Chymotrypsin Inhibitor Genes in Winged Bean [Psophocarpus tetragonolobus (L.) DC.]. J Biochem 111:249-258. https://doi.org/10.1093/oxfordjournals. jbchem.a123745

Habu Y, Fukushima H, Sakata Y, et al (1996) A gene encoding a major Kunitz proteinase inhibitor of storage organs of winged bean is also expressed in the phloem of stems. Plant Mol Biol. https://doi.org/10.1007/bf00041408

Habu Y, Peyachoknagul S, Sakata Y, et al (1997) Evolution of a multigene family that encodes the Kunitz chymotrypsin inhibitor in winged bean: a possible intermediate in the generation of a new gene with a distinct pattern of expression. Mol Gen Genet. https://doi.org/10.1007/s004380050392

Harder DK (1992) Chromosome counts in Psophocarpus. Kew Bull 47:529. https://doi.org/10.2307/4110581

Harder DK, Smartt J (1992) Further evidence on the origin of the cultivated winged bean, Psophocarpus tetragonolobus (L.) DC. (Fabaceae): chromosome numbers and the presence of a hostspecific fungus. Econ Bot 46:187-191. https://doi.org/10.1007/ BF02930637

Harding J, Lugo Lopez MA, Perez Escolar R (1978) Promiscuous root nodulation of winged beans on an oxisol in Puerto Rico (Psophocarpus tetragonolobus). Trop Agric

Hecht V (2005) Conservation of Arabidopsis flowering genes in model legumes. Plant Physiol 137:1420-1434. https://doi. org/10.1104/pp.104.057018

Hegde VS (2011) Morphology and genetics of a new found determinate genotype in chickpea. Euphytica 182:35-42. https://doi. org/10.1007/s10681-011-0447-5 
Henry CJK, Donachie PA, Rivers JPW (1985) The winged bean. Will the wonder crop be another flop? Ecol Food Nutr 16:331-338. https://doi.org/10.1080/03670244.1985.9990872

Herath HMW, Ormrod DP (1979) Effects of temperature and photoperiod on winged beans [Psophocarpus tetragonolobus (L.) D.C.]. Ann Bot 43:729-736. https://doi.org/10.1093/oxfordjour nals.aob.a085686

Hikam S, MacKown CT, Poneleit CG, Hildebrand DF (1991) Growth and $\mathrm{N}$ accumulation in maize and winged bean as affected by $\mathrm{N}$ level and intercropping. Ann Bot 68:17-22

Hikam S, Poneleit CG, MacKown CT, Hildebrand DF (1992) Intercropping of Maize and winged bean. Crop Sci 32:195. https:// doi.org/10.2135/cropsci1992.0011183X003200010040x

Hildebrand DF, Blevins DG, Hymowitz T (1981a) Cross-inoculation specificity of Psophocarpus tetragonolobus (L.) DC. Plant Soil 60:139-142. https://doi.org/10.1007/BF02377119

Hildebrand DF, Chaven G, Hymowitz T et al (1981b) Variation in protein and oil content of winged bean seeds as measured by near infrared light reflectance. Agron J 73:623-625

Hildebrand DF, Harper JE, Hymowitz T (1981c) Effects of nitrate level on nitrogen metabolism in winged bean and soya bean. Ann Bot 48:307-313. https://doi.org/10.1093/oxfordjournals.aob.a086128

Ho WK, Chai HH, Kendabie P et al (2017) Integrating genetic maps in bambara groundnut [Vigna subterranea $(\mathrm{L})$ Verdc.] and their syntenic relationships among closely related legumes. BMC Genom 18:1-9. https://doi.org/10.1186/s12864-016-3393-8

Hungria M, Phillips DA (1993) Effects of a seed color mutation on rhizobial nod -gene-inducing flavonoids and nodulation in common bean. Mol Plant Microb Interact 6:418-422. https://doi. org/10.1094/MPMI-6-418

Hungria M, Joseph CM, Phillips DA (1991) Rhizobium nod gene inducers exuded naturally from roots of common bean (Phaseolus vulgaris L.). Plant Physiol 97:759-764. https://doi. org/10.1104/pp.97.2.759

Hymowitz T, Boyd J (1977) Origin, ethnobotany and agricultural potential of the winged bean-Psophocarpus tetragonolobus. Econ Bot 31:180-188. https://doi.org/10.1007/BF02866589

IBPGR (1982) Winged bean descriptors-revised. Rome

Ikram A, Broughton WJ (1980) Rhizobia in tropical legumesVII. Effectiveness of different isolates on Psophocarpus tetragonolobus (L.) DC. Soil Biol Biochem 12:77-82. https:// doi.org/10.1016/0038-0717(80)90105-4

Iruthayathas EE, Herath HMW (1981) Nodule formation and distribution during the establishment stage of six selections of winged bean. Sci Hortic (Amsterdam) 15:1-8. https://doi. org/10.1016/0304-4238(81)90055-8

Iruthayathas EE, Vlassak K (1982) Symbiotic specificity in nodulation and nitrogen fixation between winged bean and Rhizobium. Sci Hortic (Amsterdam) 16:313-322. https://doi.org/10.1016/03044238(82)90030-9

Iruthayathas EE, Vlassak K (1987) Promiscuity of some legume species with winged bean Rhizobium strains. Sci Hortic (Amsterdam) 31:1-9. https://doi.org/10.1016/0304-4238(87)90100-2

Iruthayathas EE, Vlassak K, Laeremans R (1985) Inheritance of nodulation and N2 fixation in winged beans. J Hered 76:237-242. https://doi.org/10.1093/oxfordjournals.jhered.a110084

Jalani BS (1976) A preliminary study of the effects of gamma- irradiation on the growth of winged bean Psophocarpus tetragonolobus (L.) DC. Malays Agric Res 5:139-144

Jalani BS, Benong M, Ismail N (1983) Evaluation of F1 hybrids on winged bean (Psophocarpus tetragonolobus). 4-8

Jinsong Y, Haisheng T (2011) Study on winged bean milk. In: 2011 International conference on new technology of agricultural, IEEE, pp 814-817
Jugran HMM, Nath P, Banerji BKK, Datta SKK (1986) Gamma ray induced dwarf mutant of winged bean. J Nucl Agric Biol 15:175-178

Kadam SS, Salunkhe DK, Luh BS (1984) Winged bean in human nutrition. C R C Crit Rev Food Sci Nutr 21:1-40. https://doi. org/10.1080/10408398409527395

Kadam SS, Smithard RR, Eyre MD, Armstrong DG (1987) Effects of heat treatments of antinutritional factors and quality of proteins in winged bean. J Sci Food Agric 39:267-275. https://doi. org/10.1002/jsfa.2740390310

Kailasapathy K, Macneil JH (1985) Baking studies with winged bean (Psophocarpus tetragonolobus L. DC) flour-wheat flour blends. J Food Sci 50:1672-1675. https://doi. org/10.1111/j.1365-2621.1985.tb10562.x

Kailasapathy K, Sandrasegaram C (1983) Preliminary studies on winged bean leaf protein concentrates. In: Sri Lanka Assoc Adv Sci, pp 129-146

Kantha SS, Erdman JW (1984) The winged bean as an oil and protein source: a review. J Am Oil Chem Soc 61:515-525. https://doi. org/10.1007/BF02677021

Kantha SS, Erdman JW (1986) Winged bean as a source of protein: recent advances, pp 206-219

Kantha SS, Hettiarachchy NS, Erdman JW (1983) Laboratory scale production of winged bean curd. J Food Sci 48:441-444. https ://doi.org/10.1111/j.1365-2621.1983.tb10761.x

Karikari SK (1972) Pollination requirements of winged beans (Psophocarpus spp. Neck) in Ghana. Ghana J Agric Sci 5:235-239

Karikari SK (1978) Characters in the selection of Winged bean (Psophocarpus tetragonolobus (L.) DC.) tolerant to drought. Kade

Khan TN (1976) Papua New Guinea: a centre of genetic diversity in winged bean (Psophocarpus tetragonolobus (L.) D c.). Euphytica 25:693-705. https://doi.org/10.1007/BF00041608

Khan TN (1982) Winged bean production in the tropics. FAO Plant Production and Protection Paper 38. Rome (Italy)

Khan TN, Brock RD (1975) Mutation breeding in winged bean. In: Regional Seminar on the Use of Induced Mutation in Improvement in Grain Legume Production in South East Asia, p 8-12

Khan TN, Erskine W (1978) The adaptation of winged bean (Psophocarpus tetragonolobus (L.) DC.) in Papua New Guinea. Aust J Agric Res 29(2):281-289

Khan TN, Bohn JC, Stephenson RA (1977) Winged beans cultivation in Papua New Guinea. World Crop, Livest

Khoury CK, Bjorkman AD, Dempewolf $\mathrm{H}$ et al (2014) Increasing homogeneity in global food supplies and the implications for food security. Proc Natl Acad Sci 111:4001-4006. https://doi. org/10.1073/pnas.1313490111

Klu GYP (1996) Efforts to accelerate domestication of winged bean (Psophocarpus tetragonolobus (L.) DC.) by means of induced mutations and tissue culture. Wageningen Agricultural University, Wageningen

Klu GYP, Kumaga FK (1999) Testing of induced mutants of winged bean (Psophocarpus tetragonolobus (L.) DC.) for nodulation and phenotypic performance. Ghana J Sci 39:55-62

Koinange EMK, Singh SP, Gepts P (1996) Genetic control of the domestication syndrome in common bean. Crop Sci 36:1037. https://doi.org/10.2135/cropsci1996.0011183X003600040037x

Kortt AA (1980) Isolation and properties of a chymotrypsin inhibitor from winged bean seed (Psophocarpus tetragonolobus (L) DC.). Biochim Biophys Acta Protein Struct 624:237-248. https://doi. org/10.1016/0005-2795(80)90243-3

Kortt AA (1983) Comparative studies on the storage proteins and antinutritional factors from seeds of Psophocarpus tetragonolobus (L.) DC. from five South-East Asian countries. Qual Plant Plant Foods Hum Nutr 33:29-40. https://doi.org/10.1007/BF01093735 
Koshy EP, Alex BK, John P (2013a) Pollen Viability Studies in Psophocarpus tetragonolobus (L.) DC. Int J Appl Nat Sci 2:65-68

Koshy EP, Alex BK, John P (2013b) Clonal fidelity studies on regenerants of Psophocarpus tetragonolobus (L.) DC. using RAPD markers. The Bioscan 8:763-766

Kwak M, Velasco D, Gepts P (2008) Mapping homologous sequences for determinacy and photoperiod sensitivity in common bean (Phaseolus vulgaris). J Hered 99:283-291. https://doi. org/10.1093/jhered/esn005

Kwak M, Toro O, Debouck DG, Gepts P (2012) Multiple origins of the determinate growth habit in domesticated common bean (Phaseolus vulgaris). Ann Bot 110:1573-1580. https://doi.org/10.1093/ aob/mcs207

Lenz F, Broughton WJ (1981) Growth, photosynthesis and transpiration in Psophocarpus tetragonolobus (L.) DC. cultivar UPS 99. Photosynth Res 2:259-268. https://doi.org/10.1007/BF00056263

Lepcha P, Egan AN, Doyle JJ, Sathyanarayana N (2017) A review on current status and future prospects of winged bean (Psophocarpus tetragonolobus) in tropical agriculture. Plant Foods Hum Nutr 72:225-235. https://doi.org/10.1007/s11130-017-0627-0

Li D, Zhao X, Han Y et al (2018) Genome-wide association mapping for seed protein and oil contents using a large panel of soybean accessions. Genomics. https://doi.org/10.1016/j.ygeno .2018.01.004

Mandal SM, Chakraborty D, Dey S (2010) Phenolic acids act as signaling molecules in plant-microbe symbioses. Plant Signal Behav 5:359-368. https://doi.org/10.4161/psb.5.4.10871

Manen JF, Simon P, Van SJ et al (1991) A nodulin specifically expressed in senescent nodules of winged bean is a protease inhibitor. Plant Cell 3:259-270. https://doi.org/10.1105/ tpc.3.3.259

Martin FW, Delpin H (1978) Vegetables for the hot, humid tropics. Part I: The Winged Bean, Psophocarpus tetragonolobus. New Orleans (U.S.)

Masefield GB (1957) The nodulation of annual leguminous crops in Malaya. Emp J Exp Agric 25:139-150

Masefield GB (1961) Root nodulation and agricultural potential of the leguminous genus Psophocarpus. Trop Agric (Trinidad Tobago) 38:225-229

Massawe F, Mayes S, Cheng A (2016) Crop diversity: an unexploited treasure trove for food security. Trends Plant Sci 21:365-368. https://doi.org/10.1016/j.tplants.2016.02.006

Maxted N (1990) A phenetic investigation of Psophocarpus Neck. ex DC. (Leguminosae-Phaseoleae). Bot J Linn Soc 102:103-122

Mayes S, Massawe FJ, Alderson PG et al (2012) The potential for underutilized crops to improve security of food production. J Exp Bot 63:1075-1079. https://doi.org/10.1093/jxb/err396

Misra PN, Misra G (1985) Studies on the adaptability of winged bean (Psophocarpus tetragonolobus (L.) DC) to marginal soil conditions under semi-arid sub tropics. Qual Plant Plant Foods Hum Nutr 35:145-151. https://doi.org/10.1007/BF01092130

Mnembuka BV, Eggum BO (1995) Comparative nutritive value of winged bean (Psophocarpus tetragonolobus (L) DC) and other legumes grown in Tanzania. Plant Foods Hum Nutr 47:333-339. https://doi.org/10.1007/BF01088271

Mohanty CS, Verma S, Singh V et al (2013) Characterization of winged bean (Psophocarpus tetragonolobus (L.) DC.) based on molecular, chemical and physiological parameters. Am J Mol Biol 3:187-197. https://doi.org/10.4236/ajmb.2013.34025

Motior Rahman M (1998) Physiological response of winged bean (Psophocarpus tetragonolobus (L.) DC.) to support systems and ratooning. Faculty of Agriculture Universiti Putra Malaysia

Mukhopadhyay D (2000) The molecular evolutionary history of a winged bean $\alpha$-chymotrypsin inhibitor and modeling of its mutations through structural analyses. J Mol Evol. https://doi. org/10.1007/s002399910024

Mupangwa W, Thierfelder C, Ngwira A (2017) Fertilization strategies in conservation agriculture systems with maize-legume cover crop rotations in Southern Africa. Exp Agric 53:288-307. https ://doi.org/10.1017/S0014479716000387

Nakamura H, Abe J (1989) Growth and yields of winged bean grown in different seasons in Okinawa. Jpn Agric Res Q 23:71-77

Nangju D, Baudoin JP (1979) Performance of Winged Bean (Psophocarpus Tetragonolobus (L.) DC.) in Nigeria. J Hortic Sci 54:129-136. https://doi.org/10.1080/00221589.1979.11514860

NAS (1975a) Underexploited tropical plants with promising economic value. Washington, D.C

NAS (1975b) The winged bean: a high-protein crop for the humid tropics. National Academy of Sciences, Washington, D.C.

NAS (1981) The winged bean: a high-protein crop for the humid tropics, 2nd edn. National Academy of Sciences, Washington, D.C.

Noble TJ, Tao Y, Mace ES et al (2018) Characterization of linkage disequilibrium and population structure in a mungbean diversity panel. Front Plant Sci 8:2102. https://doi.org/10.3389/ fpls.2017.02102

Okezie BO, Martin FW (1980) Chemical composition of dry seeds and fresh leaves of winged bean varieties grown in the U.S. and Puerto Rico. J Food Sci 45:1045-1051. https://doi. org/10.1111/j.1365-2621.1980.tb07509.x

Okubo H, Masunaga T, Yamashita H, Uemoto S (1992) Effects of photoperiod and temperature on tuberous root formation in winged bean (Psophocarpus tetragonolobus). Sci Hortic (Amsterdam) 49:1-8. https://doi.org/10.1016/0304-4238(92)90137-2

Omachi M, Ishak E, Homma S, Fujimaki M (1983) Manufacturing of tofu [bean curd] from winged bean [Psophocarpus tetragonolobus] and the effect of presoaking and cooking. J Jpn Soc Food Sci Technol 30:216-220

Padulosi S, Thompson J, Rudebjer P (2013) Fighting poverty, hunger and malnutrition with neglected and underutilized species: needs, challenges and the way forward. Biodiversity International, Rome

Pate JS, Atkins CA, White ST et al (1980) Nitrogen nutrition and xylem transport of nitrogen in ureide-producing grain legumes. Plant Physiol 65:961-965

Pellegrini L, Tasciotti L (2014) Crop diversification, dietary diversity and agricultural income: empirical evidence from eight developing countries. Can J Dev Stud 35:211-227. https://doi. org/10.1080/02255189.2014.898580

Pickersgill B (1980) Cytology of two species of winged bean, Psophocarpus tetragonolobus (L.) DC. and P. scandens (Endl.) Verdc. (Leguminosae). Bot J Linn Soc 80:279-291. https://doi. org/10.1111/j.1095-8339.1980.tb01665.x

Prakash D, Misra PN, Misra PS (1987) Amino acid profile of winged bean (Psophocarpus tetragonolobus (L.) DC): a rich source of vegetable protein. Plant Foods Hum Nutr 37:261-264. https:// doi.org/10.1007/BF01091791

Prakash D, Misra PN, Misra PS (1991) Variation in protein and trypsin inhibitor activity with maturity and amino acid composition of winged bean (Psophocarpus tetragonolobus) seeds. J Sci Food Agric 57:623-626. https://doi.org/10.1002/jsfa.2740570414

Price TV, Drinkall MJ, Munro PE (1982) Studies of the incidence, severity and distribution of false rust (Synchytrium psophocarpi), leaf spot (Pseudocercospora psophocarpi) and powdery mildew (Oidium sp.) on winged bean (Psophocarpus tetragonolobus) in Papua New Gui. Ann Appl Biol 101:473-482. https://doi. org/10.1111/j.1744-7348.1982.tb00848.x

Quan MH, Jiang XH, Chen DM et al (2011) Identification and analysis of a new dwarf mutant of winged bean. Abstract retrieved May 27 th 2013 
Rachie KO (1977) The nutritional role of grain legumes in the lowland humid tropics. In: Ayanabe A, Dart PJ (eds) Biological nitrogen fixation in farming systems of the tropics. Wiley, Amsterdam

Rahman MM, Islam AM, Azirun SM, Boyce AN (2014) Tropical legume crop rotation and nitrogen fertilizer effects on agronomic and nitrogen efficiency of rice. Sci World J 2014:1-11. https:// doi.org/10.1155/2014/490841

Rattalino Edreira JI, Budakli Carpici E, Sammarro D, Otegui ME (2011) Heat stress effects around flowering on kernel set of temperate and tropical maize hybrids. F Crop Res 123:62-73. https ://doi.org/10.1016/J.FCR.2011.04.015

Repinski SL, Kwak M, Gepts P (2012) The common bean growth habit gene PvTFL1y is a functional homolog of Arabidopsis TFL1. Theor Appl Genet 124:1539-1547. https://doi.org/10.1007/s0012 2-012-1808-8

Rüegg J (1981) Effects of temperature and water stress on the growth and yield of winged bean (Psophocarpus Tetragonolobus (L.) DC.). J Hortic Sci 56:331-338. https://doi.org/10.1080/00221 589.1981.11515009

Saeed A, Darvishzadeh R (2017) Association analysis of biotic and abiotic stresses resistance in chickpea (Cicer spp) using AFLP markers. Biotechnol Biotechnol Equip 31(4):698-708. https:// doi.org/10.1080/13102818.2017.1333455

Sambudi H, Buckle KA (1991) Characteristics of winged bean (Psophocarpus tetragonolobus) seeds during soaking and boiling. J Sci Food Agric 57:585-595. https://doi.org/10.1002/ jsfa.2740570411

Sastrapradja S, Aminah Lubis SH (1975) Psophocarpus tetragonolobus as minor garden vegetable in Java. Bogor, Indonesia

Schiavinato MA, Válio IFM (1996a) Influence of photoperiod and temperature on the development of Winged Bean plants. RBrasFisiolVeg 8:105-110

Schiavinato MA, Válio IFM (1996b) Influence of staking on development of winged bean plants. RBrasFisiolVeg 8:99-103

Senayake YDA, Sumanasinghe VAD (1978) Stigma receptivity in winged bean (Psophocarpus tetragonolobus (L.) DC.). SABRAO J Breed Genet 10:116-119

Sheokand S, Dahiya P, Vincent JL, Brewin NJ (2005) Modified expression of cysteine protease affects seed germination, vegetative growth and nodule development in transgenic lines of Medicago truncatula. Plant Sci 169:966-975. https://doi.org/10.1016/j. plantsci.2005.07.003

Siebert S, Webber H, Zhao G, Ewert F (2017) Heat stress is overestimated in climate impact studies for irrigated agriculture. Environ Res Lett 12:054023. https://doi.org/10.1088/1748-9326/aa702f

Singh V, Goel R, Pande V et al (2017) De novo sequencing and comparative analysis of leaf transcriptomes of diverse condensed tannin-containing lines of underutilized Psophocarpus tetragonolobus (L.) DC. Sci Rep 7:1-13. https://doi.org/10.1038/srep44733

Sinnadurai S, Nyalemegbe KD (1979) Effect of photoperiod on the nodulation flowering and seed yield of winged bean (Psophocarpus tetragonolobus (L.) DC.). Ghana J Agric Sci 12:27-30

Smartt J (1980) Some observations on the origin and evolution of the winged bean (Psophocarpus tetragonolobus). Euphytica 29:121123. https://doi.org/10.1007/BF00037256

Stephenson RA, Kesavan V, Claydon A, et al (1979) Studies on tuber production in winged bean (Psophocarpus tetragonolobus $(\mathrm{L}$. DC.). In: Proceedings of the 5th International Symposium on Tropical Root and Tuber Crops. Laguna

Thompson AE, Haryono SK (1979) Sources of resistance to two important diseases of winged bean, Psophocarpus tetragonolobus (L.) DC. HortScience 14:532-533

Thompson AE, Haryono SK (1980) Winged bean: unexploited tropical food crop. HortScience 15:233-237
Tian Z, Wang X, Lee R et al (2010) Artificial selection for determinate growth habit in soybean. Proc Natl Acad Sci 107:8563-8568. https://doi.org/10.1073/pnas.1000088107

Tock AJ, Fourie D, Walley PG et al (2017) Genome-wide linkage and association mapping of halo blight resistance in common bean to race 6 of the globally important bacterial pathogen. Front Plant Sci 8:1170. https://doi.org/10.3389/fpls.2017.01170

Uemoto S, Fujieda K, Nonaka M, Nakamoto Y (1982) Effects of photoperiod and temperature on the raceme budding of winged beans (Psophocarpus tetragonolobus). Bull Inst Trop Agric Kyushu Univ 5:59-70

Umemoto K, Habu Y, Ohno T (1992) Analysis of differential accumulation of winged bean Kunitz chymotrypsin inhibitor mRNA species by a sequence-specific termination method. Plant Mol Biol. https://doi.org/10.1007/bf00028904

van Wyk SG, Du Plessis M, Cullis CA et al (2014) Cysteine protease and cystatin expression and activity during soybean nodule development and senescence. BMC Plant Biol 14:294. https:// doi.org/10.1186/s12870-014-0294-3

Varshney RK, Graner A, Sorrells ME (2005) Genic microsatellite markers in plants: features and applications. Trends Biotechnol 23:48-55. https://doi.org/10.1016/j.tibtech.2004.11.005

Vatanparast M, Shetty P, Chopra R et al (2016) Transcriptome sequencing and marker development in winged bean (Psophocarpus tetragonolobus; Leguminosae). Sci Rep 6:1-14. https://doi. org/10.1038/srep29070

Vavilov NI (1951) The origin, variation, immunity and breeding of cultivated plants. In: Chronica Botanica 13. Ronald Press, New York

Verdcourt B, Halliday P (1978) A revision of Psophocarpus (Leguminosae-Papilionoideae-Phaseoleae). Kew Bull 33:191. https ://doi.org/10.2307/4109575

Watanabe S, Harada K, Abe J (2012) Genetic and molecular bases of photoperiod responses of flowering in soybean. Breed Sci 61:531-543. https://doi.org/10.1270/jsbbs.61.531

Weil RR, Belmont GS (1991) Dry matter and nitrogen accumulation and partitioning in field grown winged bean. Exp Agric 27:323328. https://doi.org/10.1017/S0014479700019049

Weil RR, Khalil NA (1986) Salinity tolerance of winged bean as compared to that of soybean. Agron J 78:67. https://doi.org/10.2134/ agronj1986.00021962007800010015x

Weller JL, Ortega R (2015) Genetic control of flowering time in legumes. Front Plant Sci 6:207. https://doi.org/10.3389/ fpls.2015.00207

Wong KC (1983) Effects of daylength, temperature, light intensity and applied growth substances on the growth, flowering and tuberization of winged bean (Psophocarpus tetragonolobus (L.) DC.). Universiti Putra Malaysia

Wong KC, Schwabe WW (1979) Effects of daylength and day/night temperature on the growth, flowering and tuber formation of winged bean (Psophocarpus tetragonolobus (L.) DC.)

Wong Q, Tanzi AS, Ho W, et al (2017) Development of gene-based SSR markers in winged bean (Psophocarpus tetragonolobus (L.) DC.) for diversity assessment. Genes (Basel) 8:100. https://doi. org/10.3390/genes 8030100

Xu M, Xu Z, Liu B et al (2013a) Genetic variation in four maturity genes affects photoperiod insensitivity and PHYA-regulated post-flowering responses of soybean. BMC Plant Biol 13:91. https://doi.org/10.1186/1471-2229-13-91

Xu M, Xu Z, Liu B et al (2013b) Genetic variation in four maturity genes affects photoperiod insensitivity and PHYA-regulated post-flowering responses of soybean. BMC Plant Biol 13:1. https ://doi.org/10.1186/1471-2229-13-91

Yang S, Grall A, Chapman MA (2018) Origin and diversification of winged bean (Psophocarpus tetragonolobus (L.) DC.), a multipurpose underutilized legume. Am J Bot 105:888-897. https:// doi.org/10.1002/ajb2.1093 
Yoneyama T, Fujita K, Yoshida T et al (1986) Variation in natural abundance of $15 \mathrm{~N}$ among plant parts and in $15 \mathrm{~N} / 14 \mathrm{~N}$ Fractionation during $\mathrm{N}_{2}$ fixation in the legume-rhizobia symbiotic system. Plant Cell Physiol 27:791-799. https://doi.org/10.1093/ oxfordjournals.pcp.a077165

Yuan S, Li R, Wang L et al (2016) Search for nodulation and nodule development-related cystatin genes in the genome of soybean (Glycine max). Front Plant Sci 7:1595. https://doi.org/10.3389/ fpls.2016.01595

Zampieri M, Ceglar A, Dentener F, Toreti A (2017) Wheat yield loss attributable to heat waves, drought and water excess at the global, national and subnational scales. Environ Res Lett 12:064008. https://doi.org/10.1088/1748-9326/aa723b
Zhai H, Lü S, Liang S, et al (2014) GmFT4, a homolog of FLOWERING LOCUS T, is positively regulated by $E 1$ and functions as a flowering repressor in soybean. PLoS One. https://doi. org/10.1371/journal.pone.0089030

Zhang X, Zhai H, Wang Y et al (2016) Functional conservation and diversification of the soybean maturity gene $E 1$ and its homologs in legumes. Sci Rep 6:29548. https://doi.org/10.1038/srep29548

Publisher's Note Springer Nature remains neutral with regard to jurisdictional claims in published maps and institutional affiliations. 